\title{
Elucidation of the roles of Re in steam reforming of glycerol over Pt-Re/C catalysts
}

\author{
Zhehao Wei ${ }^{\mathrm{a}}$, Ayman M. Karim ${ }^{\mathrm{b}, ~ \&, *}$, Yan Li ${ }^{\mathrm{a}}$, David L. King ${ }^{\mathrm{b}}$, Yong Wang ${ }^{\mathrm{a}, \mathrm{b}}$ *
}

${ }^{a}$ The Gene and Linda Voiland School of Chemical Engineering and Bioengineering, Washington State University, Pullman WA 99164, USA

${ }^{\mathrm{b}}$ Institute for Integrated Catalysis, Pacific Northwest National Laboratory, Richland WA 99352, USA

${ }^{\&}$ Current address: Department of Chemical Engineering, Virginia Polytechnic Institute and State University, Blacksburg, VA 24061

* Corresponding authors: amkarim@vt.edu (A. M. Karim), yong.wang@pnnl.gov (Y. Wang) 


\section{Graphical abstract}
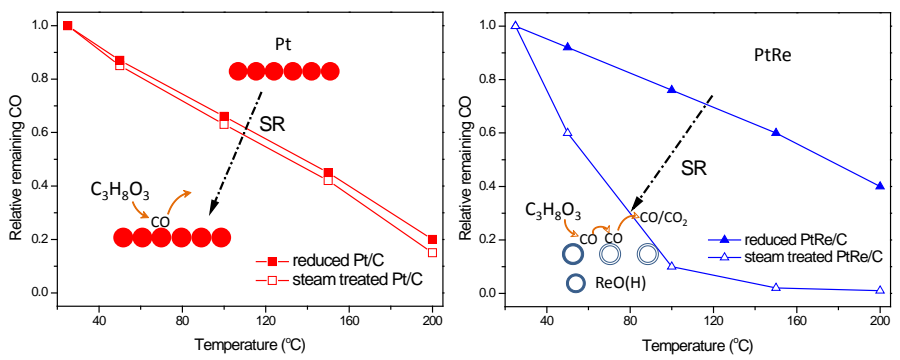

Keywords:

Reforming; Pt-Re/C; Bimetallic catalyst; CO adsorption; Rhenium oxidation, X-ray absorption, Infrared spectroscopy; In situ characterization 


\begin{abstract}
In this paper, we report the fundamental understanding of surface properties of $\mathrm{Pt} / \mathrm{C}$ and $\mathrm{Pt}-\mathrm{Re} / \mathrm{C}$ catalysts and their correlation with catalytic performance in steam reforming of glycerol. We found that the addition of Re increases the catalytic activity, $\mathrm{H}_{2} / \mathrm{CO}_{\mathrm{x}}$ ratio and $\mathrm{CO}_{2}$ selectivity. $\mathrm{N}_{2}$ physisorption, CO chemisorption, attenuated total reflectance infrared (ATR-IR), Raman and Xray absorption spectroscopy (XAS) with in situ capabilities were employed to provide the insights into the roles of Re. Using ATR-IR, we show that CO adsorption on reduced Pt-Re/C is stronger than that on Pt/C. However, CO desorption from Pt-Re/C is much facilitated than that from $\mathrm{Pt} / \mathrm{C}$ after steam pretreatment, which is more representative of the steam reforming conditions. In situ Raman and XAS studies suggest that oxidized rhenium species is formed under steam environment on the Pt-Re/C catalyst surface. The spillover of CO from neighboring Pt to such oxidized rhenium is likely the reason for the facile CO desorption, which could further react to form $\mathrm{CO}_{2}$. Such facile $\mathrm{CO}$ desorption leads to the enhanced glycerol steam reforming and water gas shift activities over Pt-Re/C catalyst.
\end{abstract}




\section{Introduction}

Catalytic processing of biomass-derived feedstocks into fuels has been proposed as a promising approach aiming at alleviating the growing global energy demand and rapid consumption of fossil fuels, especially oil[1-3]. This approach focuses on converting oxygen-containing chemicals (e.g., carbohydrates and oxygenated hydrocarbons) into all types of fuels, such as hydrogen[4, 5], alkanes[6] and furanics[7]. Steam reforming (SR) is a major process studied for the production of hydrogen.

Glycerol, abundantly available as the main by-product from biodiesel industry[8], has been studied for the production of syngas or hydrogen via catalytic steam reforming[9]. Glycerol reforming with water desirably takes place via a two-step process: decomposition (Eq. (1)) to form $\mathrm{CO}$ and $\mathrm{H}_{2}$ followed by water-gas shift (WGS, Eq. (2)), which can also be expressed in a combined process (Eq. (3)). Glycerol SR mainly employs Ni-based catalysts due to their low cost and good C-C cleavage ability, but Ni-based catalysts usually require relatively high reaction temperature $\left(>500{ }^{\circ} \mathrm{C}\right)[10]$. Pt catalysts can be very active at much lower temperatures. Soares et al. first reported low-temperature SR over supported Pt catalysts for converting glycerol to syngas, and proposed coupling of this process with Fischer-Tropsch and methanol synthesis for heat integration. Simonetti and Kunkes et al. conducted kinetic measurements for glycerol SR over carbon black (CB)-supported Pt and Pt-Re catalysts[11, 12]. The glycerol conversion rate over Pt$\mathrm{Re} / \mathrm{CB}$ was an order of magnitude higher than that over Pt/CB. The promotional role of Re was attributed to the formation of PtRe alloy, which lowers CO coverage via weakened interaction with catalyst surface as characterized by microcalorimetry and CO-TPD of selectively oxidized sample (which is more representative for the working catalyst as rhenium may get oxidized under reaction conditions[13], while platinum is not[12]), and the facilitated WGS reactions.

$$
\mathrm{C}_{3} \mathrm{H}_{8} \mathrm{O}_{3} \rightarrow 4 \mathrm{H}_{2}+3 \mathrm{CO}
$$


$\mathrm{CO}+\mathrm{H}_{2} \mathrm{O} \rightarrow \mathrm{H}_{2}+\mathrm{CO}_{2}$

$\mathrm{C}_{3} \mathrm{H}_{8} \mathrm{O}_{3}+3 \mathrm{H}_{2} \mathrm{O} \rightarrow 7 \mathrm{H}_{2}+3 \mathrm{CO}_{2}$

Despite numerous research efforts and publications in this field, detailed investigation of catalyst surface structure under reaction condition has been limited[14, 15], especially for the Pt-Re catalysts[16]. Previous work on this bimetallic system ascribed the role of Re to the modification of Pt, such as dispersion and electronic properties through the formation of a PtRe alloy[17, 18]. $\mathrm{ReO}_{\mathrm{x}}$ was also proposed to be present as a redox center to enhance the WGS activity, in which $\mathrm{ReO}_{\mathrm{x}}$ could be reduced by $\mathrm{CO}$ (generating $\mathrm{CO}_{2}$ ) and re-oxidized by $\mathrm{H}_{2} \mathrm{O}$ (forming $\mathrm{H}_{2}$ )[19]. We recently studied the catalytic performances of activated carbon-supported Pt and Pt-Re catalysts for glycerol aqueous-phase reforming (APR)[5, 16, 20]. By detailed characterizations of the catalyst surface properties using in situ spectroscopic tools, we reported that the acidity introduced by the formation of $\mathrm{ReO}_{\mathrm{x}}$ under hydrothermal conditions played an important role in affecting the reaction pathways by enhancing dehydration at the expense of C-C cleavage which lead to lower $\mathrm{H}_{2}$ selectivity. We also proposed a structure for the Pt-Re-O(H) active site under hydrothermal conditions; however, the exact Pt-Re-O(H) structure and its effect on the Pt interaction with adsorbates and catalyst activity remains unclear.

In this work, we further studied glycerol SR over activated carbon-supported Pt and Pt-Re (Pt/C and Pt-Re/C) catalysts, and attempted to correlate their surface properties with catalytic performance. We chose steam instead of aqueous phase reforming to be able to observe the changes in the $\mathrm{CO}$ and $\mathrm{CO}_{2}$ selectivities to assess the role of Re which won't be possible under aqueous phase conditions. The goal of this study was to understand the effect of steam on the structure of the Pt-Re catalyst and its effect on the interaction with adsorbates and consequently the catalytic activity. In situ spectroscopic characterizations (X-ray absorption including X-ray absorption near edge structure (XANES) and extended X-ray absorption fine structure (EXAFS), 
attenuated total reflectance infrared (ATR-IR), and Raman) were carried out on the catalysts with reducing and steam treatments to better understand the catalyst surface properties and the changes induced by exposure to steam. It is found that rhenium oxidation can readily take place upon exposure to steam which facilitates CO desorption from the catalyst surface via spillover from Pt to the neighboring oxidized Re species. Such facile CO desorption is likely the cause for the enhanced activity over Pt-Re/C catalyst.

\section{Experimental}

\subsection{Catalyst preparation}

Activated carbon support (TA 60, PICATAL) was dried at $110{ }^{\circ} \mathrm{C}$ overnight prior to use. Tetraammineplatinum(II) nitrate hexahydrate $\left(\left(\mathrm{NH}_{3}\right)_{4} \mathrm{Pt}\left(\mathrm{NO}_{3}\right)_{2} \cdot 6 \mathrm{H}_{2} \mathrm{O}\right.$, 99.999\%, Sigma-Aldrich) and perrhenic acid $\left(\mathrm{HReO}_{4}, 99.99 \%\right.$, in $65-70 \%$ aqueous solution, Sigma-Aldrich) were used as metal precursors. The same preparation method we previously reported [16, 20] was used in this work. Pt/C and Re/C were prepared by incipient wetness impregnation onto the carbon support with predetermined amount of the metal precursors dissolved in nanopure water. The impregnated samples were dried at $110^{\circ} \mathrm{C}$ for $2 \mathrm{~h}$ and calcined at $260{ }^{\circ} \mathrm{C}$ in air for another $2 \mathrm{~h}$. Pt-Re/C was prepared by impregnating Re precursor solution onto the calcined $\mathrm{Pt} / \mathrm{C}$ sample followed by the same drying and calcination steps. Activated carbon-supported catalysts were sieved to $60 \sim 100$ mesh for the activity testing. In this work, catalysts of $3 \%$ weight loading for each metal were mainly studied and compared unless otherwise mentioned.

\subsection{Catalyst characterization}

Physical adsorption and chemisorption

$\mathrm{N}_{2}$ sorption was used to determine the sample surface areas. $\mathrm{N}_{2}$ adsorption-desorption isotherms were recorded at $-196{ }^{\circ} \mathrm{C}$ on a physisorption analyzer (TriStar II, Micromeritics). The samples 
were outgassed at $110{ }^{\circ} \mathrm{C}$ for $2 \mathrm{~h}$ before the measurement. The sample specific surface areas were calculated using the Brunauer-Emmett-Teller (BET) method.

CO chemisorption was performed on a chemisorption analyzer (AutoChem II, Micromeritics). About 100 mg sample was loaded with both ends held in place by quartz wool in a quartz U-tube. The samples were first reduced with $10 \% \mathrm{H}_{2} / \mathrm{Ar}$ at $280{ }^{\circ} \mathrm{C}$ for $1 \mathrm{~h}$ and then purged with He for 30 min before cooling down to $40{ }^{\circ} \mathrm{C}$. CO pulses were introduced until saturation and the total $\mathrm{CO}$ uptake were obtained by processing the results read on the thermal conductivity detector (TCD). A CO/Pt stoichiometry of 1 was assumed to estimate the Pt dispersion. The flow rate of each gas was calibrated to $50 \mathrm{~mL} / \mathrm{min}$ and the temperature ramping rate was set to $10{ }^{\circ} \mathrm{C} / \mathrm{min}$ in all the chemisorption experiments.

\section{$X$-ray absorption spectroscopy}

The catalysts were characterized using an in-house built in situ X-ray absorption spectroscopy (XAS) cell previously reported[16]. The in situ cell is capable of probing catalysts under reaction conditions up to $1100 \mathrm{psi}$ and $700{ }^{\circ} \mathrm{C}$. It consists of a flow reactor and the cell body made of stainless steel and heated by resistive heating cartridges. An X-ray window $(1 \mathrm{~cm}$ horizontal $\times 0.5$ cm vertical) allows for measurements in transmission mode. The catalyst bed (about $60 \mathrm{mg}$, 60 100 mesh) is packed with quartz wool on both ends in a glassy carbon tube (o.d. $=6.35 \mathrm{~mm}$, i.d. = $4.1 \mathrm{~mm}$, from HTW Hochtemperatur-Werkstoffe GmbH, Germany). The tube was connected to the rest of the system via standard Swagelok fittings using graphite ferrules $\left(450{ }^{\circ} \mathrm{C}\right.$ temperature rating). The reaction temperature was controlled within $\pm 1{ }^{\circ} \mathrm{C}$, measured on the external tube wall using a Watlow temperature controller. The XAS measurements were performed at beamline X-18A at the National Synchrotron Light Source (NSLS) operated by the Synchrotron Catalysis Consortium (SCC) at Brookhaven National Laboratory (BNL). The measured Pt and Re absorption edge steps for Pt and Re for the catalysts were about 0.65. 
XANES and EXAFS data processing and analysis were performed using Athena and Artemis programs of the IFEFFIT data analysis package[21, 22]. Three scans were collected under each condition and merged after alignment using Pt (or Re) foil spectrum collected simultaneously for each scan. Scans were collected at the Pt $\mathrm{L}_{2,3}$ and Re $\mathrm{L}_{3}$ edges. For the Pt-Re catalyst, due to the overlap of the Re $\mathrm{L}_{2}(11959 \mathrm{eV})$ with the $\mathrm{Pt}_{3}(11564 \mathrm{eV})$ which limits the EXAFS signal to 9.6 $\AA^{-1}$ in k-space, we collected the EXAFS signal at the Pt $L_{2}$ edge which extends the k-range to $12.1 \AA^{-1} \cdot \chi(k)$ (where $k$ is the photoelectron wavenumber) was obtained by subtracting smooth atomic background from the normalized absorption coefficient using the AUTOBK code. The theoretical EXAFS signal was constructed using the FEFF6 code and fitted to the data in r-space using the Artemis program of the IFEFFIT package. The spectra were fitted in r-space by varying the coordination number $(\mathrm{CN})$ of the single scattering Pt-M (Re-M or Re-O) path, the bond length disorder (Debye-Waller factor), $\sigma^{2}$, the effective Pt-M (Re-M or Re-O) scattering length, and the correction to the threshold energy, $\Delta \mathrm{E}_{0} . \mathrm{S}_{0}{ }^{2}$ (passive electron reduction factor) was obtained by analyzing the spectrum for Pt and Re foils, and the best fit value ( 0.93 for $\mathrm{Pt} \mathrm{L}_{2}$, and 0.86 for both $\mathrm{Pt} \mathrm{L}_{3}$ and $\mathrm{Re} \mathrm{L}_{3}$ ) was fixed during the fitting of the catalyst samples. The values for $\mathrm{S}_{0}{ }^{2}$ are consistent with our previous work $[14,16]$ and values reported in the literature[23, 24]. Re consisted of a mixture of $\mathrm{Re}$ and $\mathrm{ReO}_{\mathrm{x}}$ and fitting the spectra to a single Re-O scattering path did not result in good fits. We used a similar model to the one proposed by Bare et al.[23] for $\mathrm{Re} / \mathrm{Al}_{2} \mathrm{O}_{3}$ where they used two Re-O scattering paths at about $1.73 \AA$ and $2.08 \AA$. The model with two Re-O scattering paths gave a much better statistical fit (reduced $\chi^{2}$ was lower by a factor of 510) than the model with a single Re-O scattering path. The k-range used for Fourier transform of the $\chi(\mathrm{k})$ was $2.5-12 \AA^{-1}$ for Pt and 2.5-13.9 $\AA^{-1}$ for the Re edge and the r-range for fitting was 1.8$3.3 \AA$ for Pt and 1.1-3.2 Å for Re unless otherwise specified.

Attenuated total reflectance infrared and Raman spectroscopies 
Attenuated total reflectance infrared (ATR-IR) characterization of the samples was performed using a home-made ATR cell with a trapezoidal ZnSe prism (FAS-ATR-M, critical angle $45^{\circ}$, Harrick Scientific) as the internal reflectance element (IRE). The catalyst sample was ground into fine powder and suspended in nanopure water (4.2 $\mathrm{mg}$ sample/mL water) under sonication to form an ink which was then coated onto the round top surface (rooftop plate, $17 \mathrm{~mm}$ in diameter) of the IRE and dried overnight to form a thin layer. The reaction cell body is made of stainless steel and a thin teflon liner is placed on the IRE slot to cushion it. Fig. 1 shows the schematic of the ATR cell. The cell is mounted on a mirror stage which consists of two mirrors coated with gold thin film for good optical reflection and positioned at an angle of $\pm 22.5^{\circ}$ from the horizontal plane in order to guide the IR beam in and out of the cell. Our design is advantageous over those previously reported[25, 26]. First, the cell has a very small internal volume (less than $10 \mu \mathrm{L}$ ), and with a silicone O-ring around the rooftop plate of the IRE it can hold at least 1000 psi hydrogen at room temperature without cracking or deforming. With the O-ring, the sealing has been tested and well maintained at $280{ }^{\circ} \mathrm{C}$ under hydrogen or nitrogen flow at ambient pressure or at $225^{\circ} \mathrm{C}$ under aqueous solution flow up to 500 psi. Second, the whole system is very compact and easy to assemble in the chamber of the infrared spectrometer (Bruker Tensor 27). It takes about 20 min to assemble for connection with the inlet and outlet and mount the cell on the mirror stage. The cell can be heated up to $280{ }^{\circ} \mathrm{C}$ (limited by temperature rating of the O-ring and ZnSe prism) by a cartridge heating element integrated with a Watlow temperature controller with PID control and a thermocouple inserted into the cell body and very close to the catalyst layer (less than $0.5 \mathrm{~mm}$ away) to measure the sample temperature. Steam was introduced by flowing He through a water bubbler kept at room temperature. 

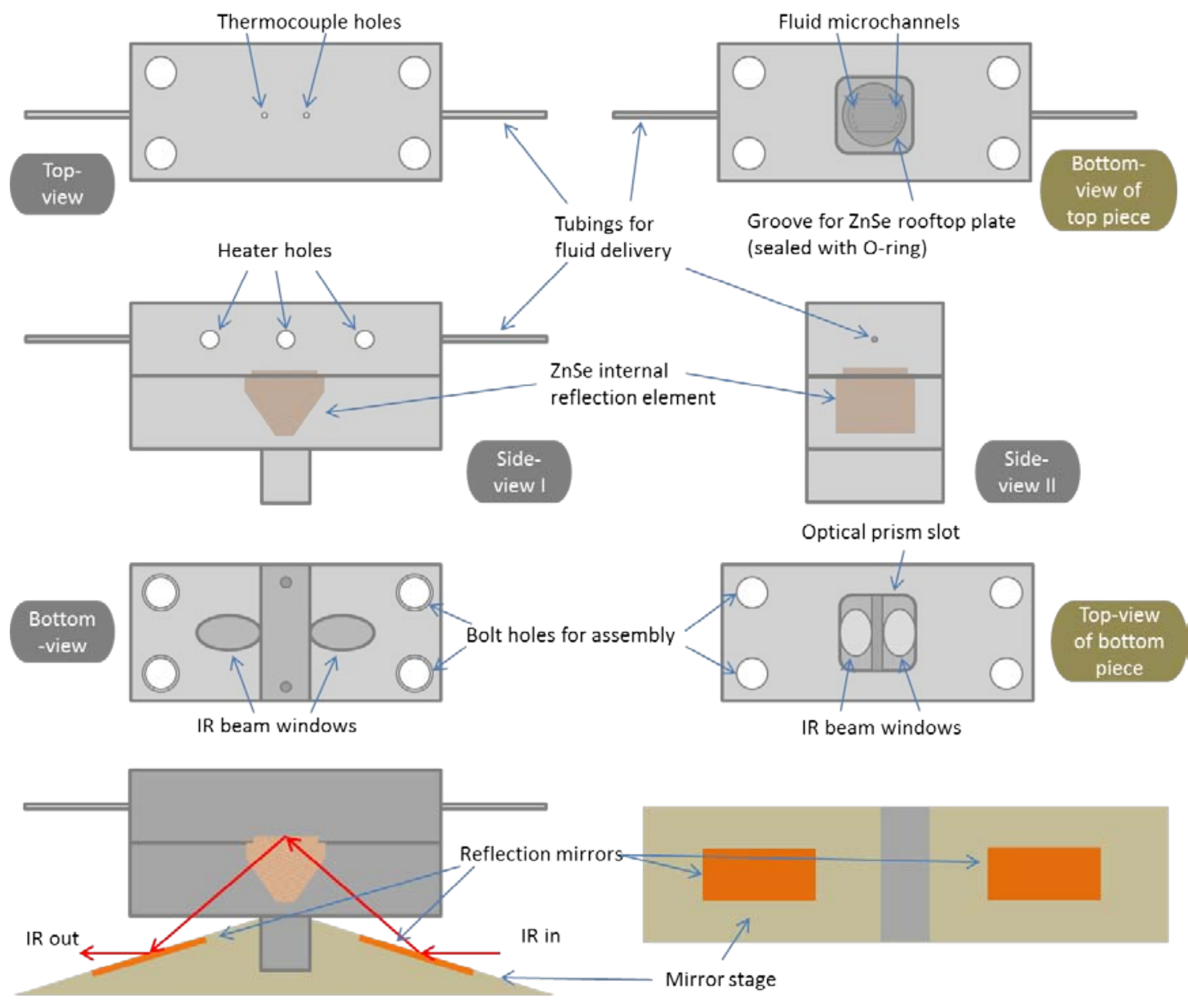

Fig. 1 Schematic of ATR cell 


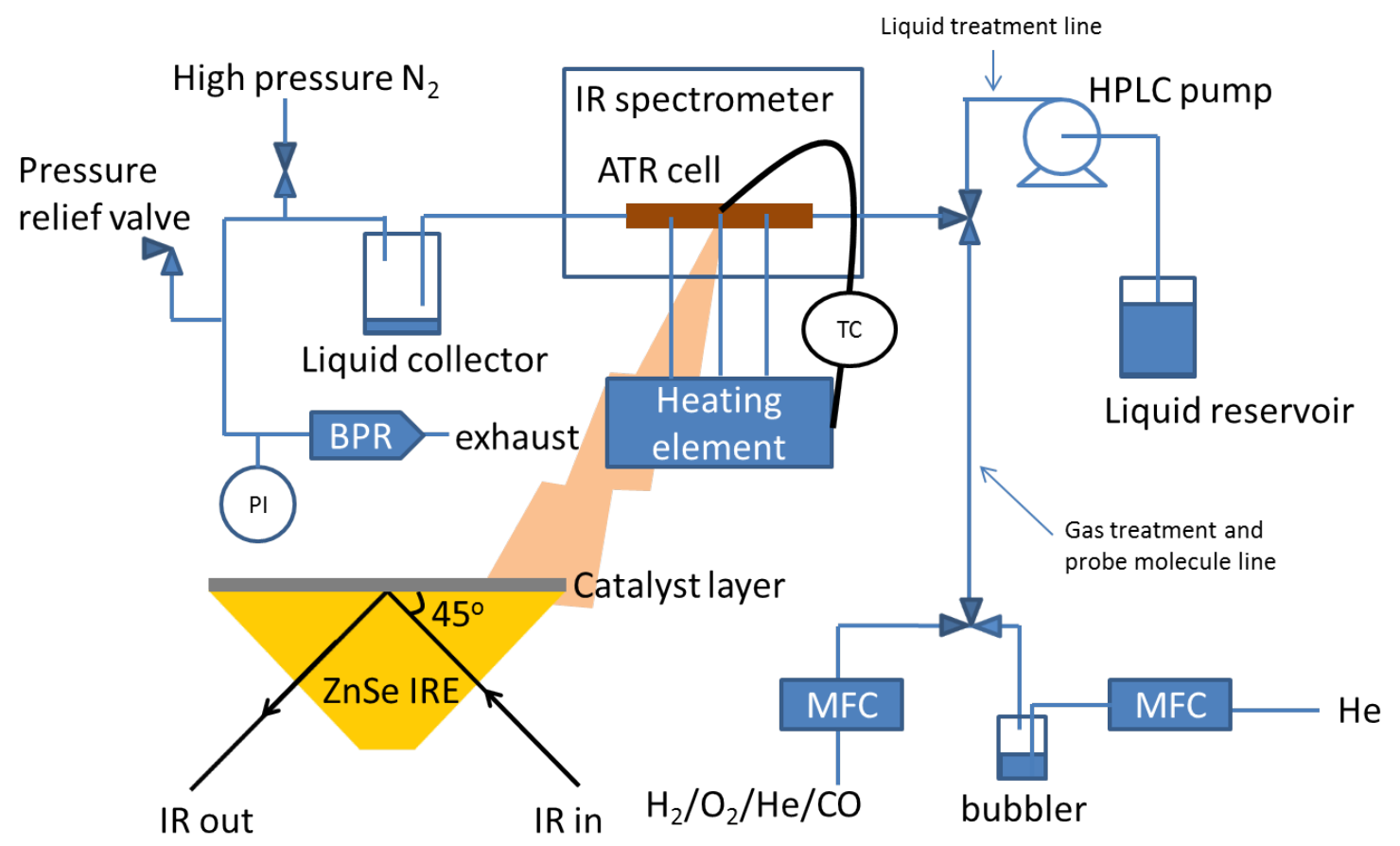

Fig. 2 Schematic of the ATR-IR experimental setup

We show that ATR-IR can be used to probe the surface of metal nanoparticles supported on carbon material, which is not possible with conventional diffuse reflectance infrared Fourier transform (DRIFT) technique due to absorption by carbon. With ATR, the evanescent wave only carries a small portion of the IR energy into the sample at the prism surface. Thus, the energy loss is not an issue.

Before each measurement, the sample was reduced in $10 \% \mathrm{H}_{2} / \mathrm{Ar}(10 \mathrm{~mL} / \mathrm{min})$ from room temperature to $280{ }^{\circ} \mathrm{C}$ at $5{ }^{\circ} \mathrm{C} / \mathrm{min}$. After $1 \mathrm{~h}$ reduction, it was switched to $10 \mathrm{~mL} / \mathrm{min}$ He and purged for 10 min before cooling down. After the sample reached room temperature for at least 10 min, a background spectrum was taken in He flow. $10 \mathrm{~mL} / \mathrm{min}$ 1\% CO/He was introduced and a series of sample scans were taken every minute until saturation. The gas was then switched to $20 \mathrm{~mL} / \mathrm{min}$ He to remove physisorbed CO from the catalyst surface then scans were collected at various desorption temperatures. The resolution of each scan was set at $4 \mathrm{~cm}^{-1}$ and 128 scans were 
averaged to generate each spectrum. For the CO desorption measurement as a function of temperature, a series of spectra in He at 200, 150, 100, 50 and $25{ }^{\circ} \mathrm{C}$ were collected before introducing $\mathrm{CO}$ and used as the background spectra for the corresponding desorption spectra.

Raman spectra of the catalyst samples were collected on a Horiba LabRAM HR Raman microscope system as previously reported[27]. The system is equipped with a $532 \mathrm{~nm}$ laser source (Ventus LP 532) and a Synapse charge coupled device (CCD) detector. Catalysts were loaded in an in situ reaction cell (Linkam CCR1000), reduced under 10\% $\mathrm{H}_{2} / \mathrm{Ar}(20 \mathrm{~mL} / \mathrm{min}$ ) at $280{ }^{\circ} \mathrm{C}$ for $1 \mathrm{~h}$, and cooled down to room temperature under He. Steam treatment was performed at $225^{\circ} \mathrm{C}$ for $1 \mathrm{~h}$ by passing $5 \mathrm{~mL} / \mathrm{min}$ He through a bubbler filled with water and kept at room temperature. The catalyst was purged with He at the same temperature for $10 \mathrm{~min}$ and then cooled down to room temperature in He. All spectra were collected at room temperature under He flow.

\subsection{Catalyst activity measurement}

Steam reforming of glycerol was performed with a fixed-bed reactor as described previously[27], which basically consists of a vaporizer, a quartz tube (i.d. $=8 \mathrm{~mm}$ ), and a condenser to separate the gas-liquid mixture. A certain amount of catalyst diluted with SiC (60 100 mesh, five times dilution in weight) was loaded in the middle of the quartz tube and held in place by quartz wool at both ends. A K-type thermocouple was attached to the outer wall of the quartz tube at the same position of catalyst bed to monitor temperature. The quartz tube was heated with a VecStar box furnace; the vaporizer and downstream line were heated with heating tapes controlled by power supplies to prevent condensation before the vapors reach the cold trap kept at $0{ }^{\circ} \mathrm{C}$. Prior to reaction, the catalysts were in situ reduced with $10 \% \mathrm{H}_{2} / \mathrm{Ar}(50 \mathrm{~mL} / \mathrm{min})$ at $280{ }^{\circ} \mathrm{C}$ for $1 \mathrm{~h}$ (10 $\left.{ }^{\circ} \mathrm{C} / \mathrm{min}\right)$, purged with $\mathrm{N}_{2}(50 \mathrm{~mL} / \mathrm{min})$ for $30 \mathrm{~min}$, and cooled down to the reaction temperature $\left(225{ }^{\circ} \mathrm{C}\right) .10$ wt.\% glycerol aqueous solution was delivered to the vaporizer with a syringe pump and then carried into the reactor (the flow rate of steam is about 46 times that of 
glycerol used in this study) with flowing $\mathrm{N}_{2}$ (also serving as an internal analytical standard). The liquid and carrier gas flow rates were varied to adjust the gas hourly space velocity (GHSV) while the ratio between them was kept constant in this study to maintain the identical inlet feed molar composition (partial pressure). The gas products were passed through a drying column (anhydrous $\mathrm{CuSO}_{4}$, drierite) and analyzed with an online Agilent 490 micro GC having four independent modules (a Molsieve column, a CP-PoraPLOT U column, an aluminum oxide column, and a CP-Sil 5CB column, all with TCDs). The flow rate of dry effluent gas was recorded periodically. The liquid product was condensed in the cold trap and drained periodically for offline analysis using a Waters Breeze 2 HPLC equipped with a Bio-Rad Aminex HPX-87H ion exclusion column $(300 \mathrm{~mm} \times 7.8 \mathrm{~mm})$ and a refractive index detector. The mobile phase in HPLC was $5 \mathrm{mM} \mathrm{H}_{2} \mathrm{SO}_{4}$ aqueous solution at a flow rate of $0.6 \mathrm{~mL} / \mathrm{min}$. The column and detector temperatures were set to 60 and $55^{\circ} \mathrm{C}$, respectively. The liquid composition was quantified by external calibration with standard chemicals. Carbon balance was calculated as the amount of carbon from the identified gas and liquid products divided by that in the form of glycerol fed into the reactor during a certain period of reaction time. The carbon balance was typically above 95\%. Carbon-based product selectivity (except for hydrogen) was calculated by dividing the amount of carbon in each product by the carbon in the form of glycerol fed into the reactor during a certain period of reaction time. Hydrogen selectivity is calculated by $\mathrm{H}_{2}$ produced divided by the maximum $\mathrm{H}_{2}$ molecules producible per glycerol molecule converted via steam reforming (ideally the conversion coefficient is 7 according to Eq. (3)) shown in Eq. (4). The turnover frequency (TOF) was calculated as either the consumption rate of glycerol or the formation rate of each product divided by the Pt dispersion listed in Table 1.

$\mathrm{H}_{2}$ selectivity $=\mathrm{H}_{2}$ production rate $/(7 \times$ glycerol conversion rate $)$

\section{Results and discussion}




\subsection{Surface area and Pt dispersion}

Table 1 summarizes the BET surface area and CO chemisorption results for Pt/C, Re/C, Pt-Re/C along with the carbon support. Apparently, loading of Pt, Re, or Pt-Re to the carbon support has negligible effect on its BET surface area, suggesting that Pt, Re, or Pt-Re are highly dispersed and there is minimum pore plugging by loading these metals.

Table 1 Sample surface area and calculated Pt dispersion by CO chemisorption

\begin{tabular}{llllll}
\hline Sample & Pt\% & Re\% & BET surface area $\left(\mathrm{m}^{2} / \mathrm{g}\right)$ & CO uptake $(\mu \mathrm{mol} / \mathrm{g})$ & Pt dispersion $(\%)$ \\
\hline $\mathrm{C}$ & 0 & 0 & 1078 & - & - \\
$\mathrm{Pt} / \mathrm{C}$ & 3 & 0 & 1097 & 131 & 85.1 \\
$\mathrm{Pt}-\mathrm{Re} / \mathrm{C}$ & 3 & 3 & 1012 & 72 & 46.6 \\
$\mathrm{Re} / \mathrm{C}$ & 0 & 3 & 1050 & 2 & - \\
\hline
\end{tabular}

Since hydrogen spillover can cause inaccurate estimation of noble metal dispersion, we performed chemisorption experiment with CO probe molecule[11, 20, 28] to determine the Pt dispersion which is generally accepted for this application. The stoichiometry of CO/Pt is assumed to be 1 . We note, besides linear adsorption, CO molecule also chemisorbs on bridge and hollow Pt sites. However, these latter modes only account for a very small portion on supported Pt catalysts[26]. As can be seen in Table 1, adding 3\%Re to 3\%Pt/C decreased the Pt dispersion from $85.1 \%$ to $46.6 \%$ (by about half) which is consistent with our previous report[20] that adding Re to Pt/C resulted in poorer Pt dispersion.. We previously proposed several factors to account for this disparity, including bigger Pt-Re particles and more surface coverage by Re species. Since we previously showed that the particle size and distribution of $\mathrm{Pt} / \mathrm{C}$ and $\mathrm{Pt}-\mathrm{Re} / \mathrm{C}$ were similar[29], the first factor is less likely. On the other hand, for the same Pt and Pt-Re particle size, if we assume a homogeneous geometric dilution of the Pt particles by Re, the Pt dispersion should be unaffected. Thus, such a big drop in Pt dispersion (from 85.1\% to 46.6\%) cannot be expected based on uniform bulk dilution. Consequently, preferential surface coverage by Re (oxide) species due to its high surface dispersion[12] is reasonable and could be the cause for the 
decrease of CO adsorption. The negligible CO adsorption on Re/C sample ( $2 \mu \mathrm{mol} / \mathrm{g})$ also agrees well with studies on supported Re catalysts reported by different groups[11, 12, 20, 30]. In the present study, the degree of Re reduction may be limited by the temperature used $\left(280{ }^{\circ} \mathrm{C}\right)[31]$ and thus the available surface binding sites for $\mathrm{CO}$ adsorption are negligible considering that $\mathrm{CO}$ does not adsorb on $\mathrm{ReO}_{\mathrm{x}}$ species[28, 32] and that the adsorption temperature $\left(40{ }^{\circ} \mathrm{C}\right)$ is not favorable to CO adsorption on metallic Re site[30, 33].

\subsection{Catalytic reactivity in steam reforming of glycerol}

The prepared catalyst samples were evaluated in steam reforming of glycerol. A blank test with activated carbon support was performed as the baseline giving negligible activity (glycerol conversion $<0.1 \%$ ). Steam reforming of glycerol over Pt/C and Pt-Re/C catalysts was examined at various conversions by adjusting the GHSV, and the results at relatively low conversions ( 20\%) are compared in Fig. 3. A control test with 3\%Re/C resulted in less than 1\% conversion of glycerol for all the GHSVs studied. In our experiments $\mathrm{H}_{2}, \mathrm{CH}_{4}, \mathrm{CO}, \mathrm{CO}_{2}$ were the main gas products along with trace amounts of $\mathrm{C}_{2} \mathrm{H}_{4}, \mathrm{C}_{2} \mathrm{H}_{6}$ and $\mathrm{C}_{3} \mathrm{H}_{8}$. The liquid phase, in addition to the unreacted glycerol, consisted of acetol, ethylene glycol (EG), alcohols (methanol and ethanol), and acids (lactic acid (LA) and acetic acid (AA)) which were quantified by HPLC (results can be found in Table 2). Trace amounts of other intermediate products in the liquid phase were also identified, such as glyceraldehyde and pyruvaldehyde, but not quantified. 
Table 2 Steam reforming of glycerol over Pt and Pt-Re catalysts supported on activated carbon (reaction temperature $225{ }^{\circ} \mathrm{C}$, operated under ambient pressure with inlet molar composition of $1.4 \%$ glycerol, $64.7 \% \mathrm{H}_{2} \mathrm{O}$ balanced with $\mathrm{N}_{2}$ ); catalysts were in situ reduced in $10 \% \mathrm{H}_{2} / \mathrm{Ar}(50$ $\mathrm{mL} / \mathrm{min}$ ) at $280^{\circ} \mathrm{C}$ for $1 \mathrm{~h}$, purged with $\mathrm{N}_{2}$ for $30 \mathrm{~min}$ and cooled down to $225^{\circ} \mathrm{C}$ prior to feed injection.

\begin{tabular}{|c|c|c|c|c|c|c|c|c|c|c|c|c|c|c|c|}
\hline \multirow[t]{2}{*}{ Catalyst } & \multirow{2}{*}{$\begin{array}{l}\text { GHSV } \\
\left(10^{3} \mathrm{~h}^{-1}\right)\end{array}$} & \multirow[t]{2}{*}{$\mathrm{X}_{\mathrm{T}}(\%)$} & \multirow[t]{2}{*}{$X_{G}(\%)$} & \multicolumn{4}{|c|}{$\begin{array}{l}\text { Gas product selectivity } \\
\text { (C-based, \%, dry basis) }^{\mathrm{a}}\end{array}$} & \multirow[t]{2}{*}{$\mathrm{CO} / \mathrm{CO}_{2}$} & \multirow[t]{2}{*}{$\mathrm{X}_{\mathrm{L}}(\%)$} & \multicolumn{6}{|c|}{ Liquid product selectivity (C-based, \%) } \\
\hline & & & & $\mathrm{H}_{2}{ }^{\mathrm{C}}$ & $\mathrm{CH}_{4}$ & $\mathrm{CO}$ & $\mathrm{CO}_{2}$ & & & LA & AA & EG & acetol & $\mathrm{MeOH}$ & EtOH \\
\hline \multirow{3}{*}{$3 \% \mathrm{Pt} / \mathrm{C}$} & 10 & 56.0 & 45.2 & 41.5 & 3.3 & 73.6 & 3.9 & 18.9 & 10.8 & 1.1 & 0.6 & 2.0 & 14.2 & 1.2 & 0.1 \\
\hline & 20 & 35.7 & 32.2 & 48.2 & 2.3 & 83.7 & 3.9 & 21.5 & 3.5 & 0.9 & 0.5 & 1.3 & 7.1 & 0.4 & 0 \\
\hline & 30 & 24.1 & 22.6 & 51.8 & 2.4 & 85.0 & 5.5 & 15.5 & 1.5 & 1.2 & 0.2 & 0.6 & 5.0 & 0.1 & 0 \\
\hline \multirow{4}{*}{ 3\%Pt-3\%Re/C } & 25 & 59.4 & 43.9 & 45.2 & 1.8 & 72.9 & 6.1 & 12.0 & 15.5 & 3.4 & 1.0 & 1.6 & 11.3 & 1.6 & 0.3 \\
\hline & 51 & 38.4 & 30.5 & 46.9 & 1.3 & 72.1 & 5.9 & 12.2 & 7.9 & 4.5 & 1.2 & 1.7 & 11.4 & 1.5 & 0.3 \\
\hline & 102 & 21.0 & 18.2 & 53.4 & 0 & 79.5 & 6.5 & 12.2 & 2.8 & 4.8 & 0.8 & 1.6 & 6.2 & 0.5 & 0.1 \\
\hline & 153 & 18.8 & 16.8 & 56.4 & 0 & 83.4 & 5.8 & 14.4 & 2.0 & 4.3 & 0.3 & 1.0 & 4.8 & 0.2 & 0.2 \\
\hline
\end{tabular}

$\mathrm{X}_{\mathrm{T}}, \mathrm{X}_{\mathrm{G}}, \mathrm{X}_{\mathrm{L}}$ : total conversion, conversion to gas and liquid products, respectively; LA: lactic acid, AA: acetic acid, EG: ethylene glycol.

${ }^{a}$ Gas products mainly consisted of $\mathrm{H}_{2}, \mathrm{CH}_{4}, \mathrm{CO}$ and $\mathrm{CO}_{2}$. $\mathrm{C}_{2}$ and higher hydrocarbons $\left(\mathrm{C}_{2} \mathrm{H}_{4}, \mathrm{C}_{2} \mathrm{H}_{6}\right.$ and $\left.\mathrm{C}_{3} \mathrm{H}_{8}\right)$ unitedly constituted less than $1 \%$ of the gas products, and thus are not included in this table.

${ }^{\mathrm{b}}$ Experimental data shown in this table was obtained at total carbon loss within 5\%, most of which was caused by the unknowns in liquid products

${ }^{\mathrm{c}} \mathrm{H}_{2}$ selectivity is calculated according to Eq. (4). 


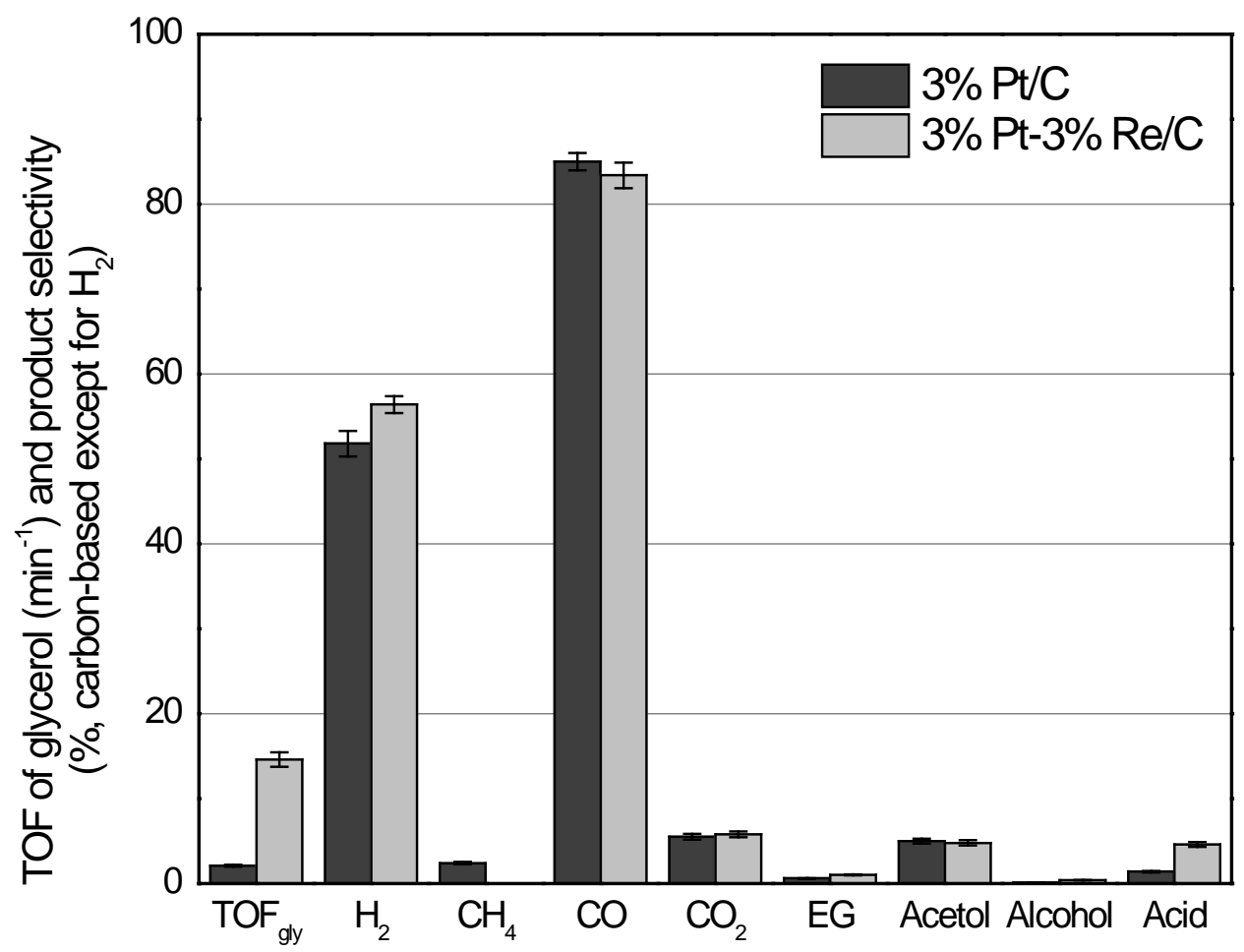

Fig. 3 TOF of glycerol $\left(\mathrm{min}^{-1}\right)$ and product selectivity for steam reforming of $10 \mathrm{wt} . \%$ glycerol aqueous solution over 3\%Pt/C and 3\%Pt-3\%Re/C at $225{ }^{\circ} \mathrm{C}$ and ambient pressure. The inlet feed molar composition was kept constant for all the reactions at $1.4 \%$ glycerol, $64.7 \% \mathrm{H}_{2} \mathrm{O}$ balanced with $\mathrm{N}_{2}$. GHSV was held at $30,000 \mathrm{~h}^{-1}$ for $3 \% \mathrm{Pt} / \mathrm{C}$ and $153,000 \mathrm{~h}^{-1}$ for $3 \% \mathrm{Pt}-3 \% \mathrm{Re} / \mathrm{C}$ for comparison at a similar conversion level ( 20\%).

As shown in Fig. 3, significant difference in activity (glycerol TOF calculation based on Pt dispersion values in Table 1 and assuming CO/Pt stoichiometry of 1) was observed. It is generally agreed that adding Re to Pt catalyst can promote the catalyst activity. Simonetti et al.[11] conducted steam reforming of glycerol at $225{ }^{\circ} \mathrm{C}$ and found that the TOFs of $\mathrm{H}_{2}$ and $\mathrm{CO}$ over Pt$\mathrm{Re} / \mathrm{C}$ (17 and $12 \mathrm{~min}^{-1}$, respectively) are about ten times that over Pt/C (1.6 and 1.3, respectively). Our results agree well with this trend that Re addition enhanced the $\mathrm{H}_{2}$ and $\mathrm{CO}$ production rate. Specifically, compared to the Pt catalyst, about a factor of 7 enhancement in the TOF of glycerol 
was observed for the bimetallic Pt-Re catalyst but the selectivity to $\mathrm{H}_{2}, \mathrm{CO}$ and $\mathrm{CO}_{2}$ is about the same for both Pt and Pt-Re catalysts. The TOFs of $\mathrm{H}_{2}$ and $\mathrm{CO}$ were 7 and $5 \mathrm{~min}^{-1}$ over $3 \% \mathrm{Pt} / \mathrm{C}$, and 53 and $37 \mathrm{~min}^{-1}$ over 3\%Pt-3\%Re/C, respectively, again about a factor of 7 enhancement for Pt-Re compared to Pt catalyst. In the present study, the liquid products mainly consisted of acetol, EG, LA, AA, ethanol and methanol which were quantified by means of HPLC. Little difference in acetol, EG, ethanol and methanol selectivity was observed between Pt/C and Pt-Re/C catalysts. The product analysis for the GHSVs studied is listed in Table $2 . \mathrm{H}_{2}$ and CO constituted the major gas product. Compared with $\mathrm{Pt} / \mathrm{C}$, Pt-Re/C showed a higher $\mathrm{H}_{2} / \mathrm{CO}_{\mathrm{x}}$ ratio as well as higher $\mathrm{CO}_{2}$ selectivity. The details will be discussed in section 3.3.

\subsection{Catalyst properties under different environment and the role of Re}

To understand the effect of Re on the properties of Pt, we investigated the electronic properties of the $\mathrm{Pt} / \mathrm{C}$ and $\mathrm{PtRe} / \mathrm{C}$ catalysts under both inert atmosphere and steam containing environment to simulate the reaction conditions. We used a combination of XAS, ATR-IR of adsorbed CO and Raman spectroscopies, and the results are presented below into two separate sections based on the gaseous environment studied.

\section{Properties under inert/reducing environment}

We investigated the structure of the supported nanoparticles by EXAFS, and the fitting results for the reduced $\mathrm{Pt} / \mathrm{C}$ and $\mathrm{Pt}-\mathrm{Re} / \mathrm{C}$ catalysts are shown in Table 3. The fitting results for the calcined catalyst (Table S1) and the comparison of the fit to the experimental data in r-space (Fig. S1) can be found in the supplementary information. Despite the higher dispersion measured by CO chemisorption, the $\mathrm{CN}_{\mathrm{Pt} \text {-metal }}$ in $\mathrm{Pt} / \mathrm{C}$ (8.5) was larger than that in Pt-Re/C (7.0) which was

surprising. Additionally, the bond disorder $\left(\sigma^{2}\right)$ was larger for $\mathrm{Pt} / \mathrm{C}$ than $\mathrm{Pt}-\mathrm{Re} / \mathrm{C}$ which is opposite to the typical size effect where smaller particles (smaller $\mathrm{CN}$ ) are more disordered than 
larger particles[34-36]. This discrepancy could be a result of the alloy formation which in addition to affecting the size of the nanoparticles, could also affect the structure and distortion of the nanoparticles which in turn affects the coordination numbers and bond disorder obtained from EXAFS[37, 38]. The results at the $\mathrm{Re}_{3}$ edge show that Re exists as a mixture of $\operatorname{Re}$ and $\mathrm{ReO}_{\mathrm{x}}$. Using a linear combination fit of Re foil and the calcined catalyst as standards, we estimated that only $52 \%$ of the Re was reduced to metallic state. The Re-metal (Re-M) bond distance was shorter than that of Pt-metal (Pt-M), and the $\mathrm{CN}_{\mathrm{Re}-\mathrm{M}}$ was slightly lower than $\mathrm{CN}_{\mathrm{Pt}-\mathrm{M}}$. Since we reported previously that the catalyst preparation used in this study resulted in large compositional variation[29], the large difference in the Re-M and Pt-M bond distances obtained from EXAFS could be due to the presence of a mixture of Pt-rich and Re-rich particles and/or Re enrichment on the surface. However, the model of $\mathrm{Re} / \mathrm{ReO}_{\mathrm{x}}$ enrichment on the surface of the nanoparticles is consistent with the coordination numbers and lower dispersion measured by CO chemisorption. Additionally, since atoms on the surface of the nanoparticles are more disordered than atoms in the bulk[37, 39] the $\mathrm{Re} / \mathrm{ReO}_{\mathrm{x}}$-rich surface model is also consistent with the higher disorder of ReM bonds compared to Pt-M as seen from the $\sigma^{2}$ reported in Table 3.

Table 3 EXAFS fitting results for the Pt/C and Pt-Re/C catalysts at the $\mathrm{Pt} \mathrm{L}_{2}$ and $\mathrm{Re} \mathrm{L}_{3}$ edges. The catalysts were reduced at $300{ }^{\circ} \mathrm{C}$ in $100 \% \mathrm{H}_{2}$ and the EXAFS spectra were collected at 225 ${ }^{\circ} \mathrm{C}$ in $100 \% \mathrm{H}_{2}$ flow. The numbers in parentheses indicate the statistical error in the most significant digit obtained from the fit in Artemis (e.g., 6.2(8) $\equiv 6.2 \pm 0.8$ ).

\begin{tabular}{|c|c|c|c|c|c|c|c|}
\hline Edge & Sample & Absorber-backscatterer pair & $\mathrm{CN}$ & $\mathrm{R}(\AA)$ & $\sigma^{2}\left(\AA^{2}\right)$ & $\Delta \mathrm{E}_{0}(\mathrm{eV})$ & Reduced $\chi^{2}$ \\
\hline \multirow{2}{*}{$\mathrm{Pt} \mathrm{L}_{2}$} & $\mathrm{Pt} / \mathrm{C}$ & Pt-Pt & $8.5(9)$ & $2.749(7)$ & $0.012(1)$ & $5.6(8)$ & 25 \\
\hline & $\mathrm{Pt}-\mathrm{Re} / \mathrm{C}$ & Pt-M & $7.0(8)$ & $2.735(9)$ & $0.009(1)$ & $6.2(7)$ & 86 \\
\hline \multirow{3}{*}{$\operatorname{Re} \mathrm{L}_{3}$} & \multirow{3}{*}{ Pt-Re/C } & Re-M & $6.2(8)$ & $2.677(4)$ & $0.013(1)$ & $3.2(1.5)$ & 29 \\
\hline & & Re-O1 & $1.1(3)$ & $1.74(1)$ & $0.006(2)$ & $1.0(1.5)$ & \\
\hline & & $\mathrm{Re}-\mathrm{O} 2$ & $1.2(4)$ & $2.00(1)$ & $0.006(2)$ & $1.0(1.5)$ & \\
\hline
\end{tabular}

As a key gas product of steam reforming of glycerol, CO can be a good probe molecule to study the catalyst surface[12]. The theoretical and experimental results on the interaction of CO with Pt-Re bimetallic catalysts in literature are somewhat contradictory[16, 20]. A surface science 
study by Ramstadt et al.[40] showed a weaker Pt-CO bond on Re/Pt(111) surface alloy than that on Pt(111). DFT calculations by Ishikawa et al.[41] and Greeley et al.[42] implied that CO binding energy could be reduced by about $30 \%$ in the cases of Pt-Re cluster, alloy or near surface alloy. However, stronger CO adsorption on Pt-Re catalyst was also reported experimentally. For example, Sato et al.[43] performed CO FT-IR over Pt-Re/TiO ${ }_{2}$ and found that the CO adsorption peak red-shifted upon higher Re/Pt ratio. Additionally, a stronger binding of CO was also evidenced by the CO desorption profile. Moreover, according to Kunkes et al.[12], CO appeared to require higher temperature to desorb from reduced $\mathrm{Pt}-\mathrm{Re} / \mathrm{C}$ than $\mathrm{Pt} / \mathrm{C}$. This discrepancy was previously attributed to particle size effect based on the report by Ruettinger et al.[44] that CO adsorption on Pt-Re is weaker on small particles and stronger on larger particles[20].

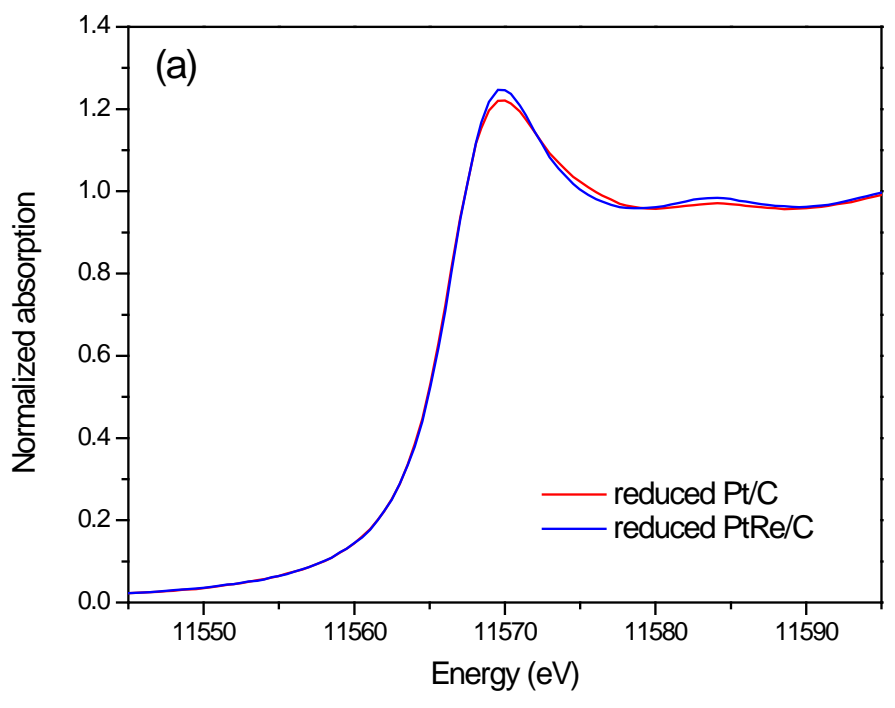




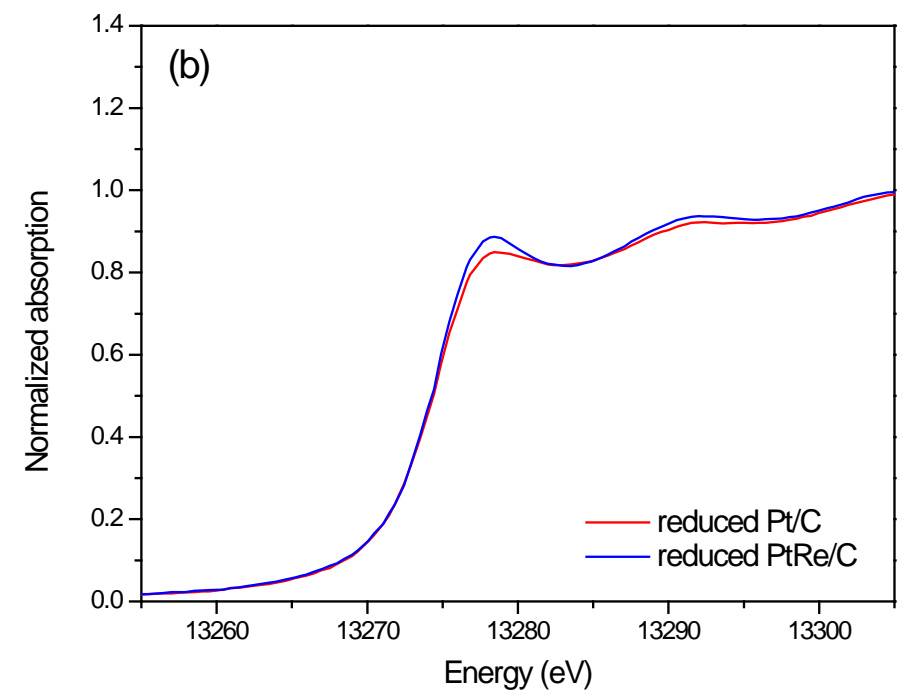

Fig. 4 Pt $\mathrm{L}_{3}$ (a) and $\mathrm{L}_{2}$ (b) XANES for reduced Pt/C and Pt-Re/C in He at $225^{\circ} \mathrm{C}$

In the present work, we attempt to unravel the discrepancy first by investigating the electronic and geometric modification of Pt by the addition of Re by means of XANES. Fig. 4 shows the spectra of Pt $\mathrm{L}_{2,3}$ edges for Pt/C and Pt-Re/C under He (bare atoms without adsorbates). The edge position was almost identical for Pt in both catalysts while the white line intensity and peak width were slightly different. The features after the white line were similar for $\mathrm{Pt} / \mathrm{C}$ and $\mathrm{Pt}-\mathrm{Re} / \mathrm{C}$; however, the oscillations were more intense for Pt-Re/C which could be due to the contributions from Pt-Pt and Pt-Re/ReO in the Pt-Re nanoparticles. The peak width was slightly narrower for $\mathrm{Pt}-\mathrm{Re} / \mathrm{C}$ at the $\mathrm{Pt} \mathrm{L}_{3}$ edge while it was slightly broader at the $\mathrm{Pt} \mathrm{L}_{2}$ edge. As $\mathrm{Pt} \mathrm{L}_{3}$ XANES is a measure of the local d density of states (DOS) projected on the Pt atom[45], a narrower Pt d-band in $\mathrm{Pt}-\mathrm{Re} / \mathrm{C}$ compared to that in $\mathrm{Pt} / \mathrm{C}$ can thus be inferred. The white line intensity was slightly higher for Pt-Re/C at both the $\mathrm{L}_{2,3}$ edges. Since the white line intensity (peak area above the edge) at the $P t L_{2,3}$ edges is proportional to the number of d-electron vacancies[45, 46], these results suggest that more Pt d-band vacancies are present in Pt-Re/C compared to Pt/C. Mansour et al. developed a procedure to estimate the number of $\mathrm{d}$ holes using the spectrum of a Pt foil as a 
reference and assuming that the bulk ratio of $5 / 2$ to $3 / 2 \mathrm{~d}$ holes is $14[45]$. According to their procedure, we estimated the fractional change in the total number of unfilled d-band states compared to the reference platinum foil $\left(\mathrm{f}_{\mathrm{d}}\right)$ using the following relation:

$$
f_{d}=\frac{\sigma_{3} \Delta A_{3}+\left(1.11 \sigma_{2} \Delta A_{2}\right)}{\sigma_{3} A_{3 r}+\left(1.11 \sigma_{2} A_{2 r}\right)}
$$

The $\Delta \mathrm{A}_{\mathrm{i}}\left(\mathrm{i}=2\right.$ for $\mathrm{L}_{2}$ and 3 for $\left.\mathrm{L}_{3}\right)$ values are the areas for the attributed electronic transitions to unfilled d-states in the difference XANES spectra between the catalyst samples and the Pt reference foil (from 10 below $\mathrm{E}_{0}$ to 14 above $\mathrm{E}_{0}$ ) and are normalized by multiplying the $\mathrm{X}$-ray cross section at the same edge, $\sigma_{\mathrm{i}}$ (at $\mathrm{L}_{3}$ edge $\sigma_{3}=117.1 \mathrm{~cm}^{2} / \mathrm{g}$, and at $\mathrm{L}_{2}$ edge $\sigma_{3}=54.2 \mathrm{~cm}^{2} / \mathrm{g}$ ) . The denominator in Eq. (5) is estimated using the difference between the Pt foil $\mathrm{L}_{3}$ and $\mathrm{L}_{2}$ areas from -10 to $40 \mathrm{eV}$ above the edge as described by Mansour et al.[45].

$A_{3 r}=\left(L_{3}-L_{2}\right)$ Area $\times\left(1+h_{3 / 2} / h_{5 / 2}\right)$ and $A_{2 r}=\left(L_{3}-L_{2}\right)$ Area $\times h_{3 / 2} / h_{5 / 2}$, where $h_{5 / 2} / h_{3 / 2}$ is assumed to be equal to $14[45]$. Using the values above and the $L_{3}$ and $L_{2}$ areas for the Pt foil, $\sigma_{3} A_{3 r}+1.11 \sigma_{2} A_{2 r}=$ $613 \mathrm{eV} \mathrm{cm}^{2} / \mathrm{g}$.

Table $4 \mathrm{Pt} \mathrm{L}_{2,3}$ difference areas and fractional change in unocuppied d states (relative to Pt foil) for $\mathrm{Pt} / \mathrm{C}$ and $\mathrm{PtRe} / \mathrm{C}$ under He at $225^{\circ} \mathrm{C}$

\begin{tabular}{llll}
\hline Sample & $\Delta \mathrm{A}_{2}\left(\mathrm{eV} \mathrm{cm}^{2} / \mathrm{g}\right)$ & $\Delta \mathrm{A}_{3}\left(\mathrm{eV} \mathrm{cm}^{2} / \mathrm{g}\right)$ & $\mathrm{f}_{\mathrm{d}}$ \\
\hline $\mathrm{Pt} / \mathrm{C}$ & 0.92 & 0.08 & 0.08 \\
Pt-Re/C & 0.69 & 0.04 & 0.1 \\
\hline
\end{tabular}

It can be seen from Table 4 that according to $\Delta \mathrm{A}_{2}$ and $\Delta \mathrm{A}_{3}$, Re appears to increase the electron deficiency of Pt under He (bare particles). However, the extent of this increase $\left(f_{d}\right)$ is almost negligible. From the analysis of the $\mathrm{Pt}_{2,3}$ XANES of the bare particles we can conclude that the formation of Pt-Re alloy results in an insignificant charge transfer between Pt and Re and in a possible narrowing of the Pt d-DOS, likely as a result of the hybridization between the Pt and Re 
d-bands. Since the charge transfer between Pt and Re is minimal, a narrowing of the d-DOS should be expected to result in the upward shift of the d-band center relative to the Fermi level according to the "rectangular band" model[47]. Therefore, it should be expected that Pt-Re would adsorb CO more strongly since the electron back-donation from the metal d-band has a strong effect on the CO binding strength[26].

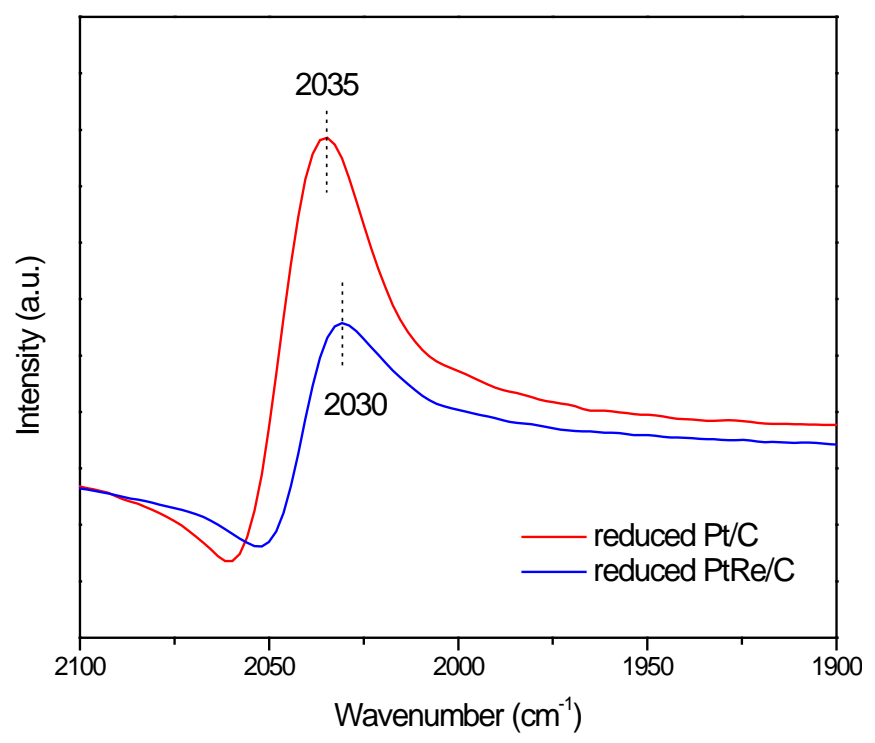

Fig. 5 CO ATR-IRS of reduced 3\%Pt/C and 3\%Pt-3\%Re/C at $25^{\circ} \mathrm{C}$

CO adsorption on reduced Pt/C and Pt-Re/C catalysts were further probed by in situ ATR-IR spectroscopy to understand their surface interactions. As shown in Fig. 5, at $25{ }^{\circ} \mathrm{C} \mathrm{CO}$ adsorption on reduced 3\%Pt/C shows a peak at $2035 \mathrm{~cm}^{-1}$ which can be ascribed to the linear CO adsorption $\left(\mathrm{CO}_{\mathrm{L}}\right)$ on $\mathrm{Pt}^{0}$ site[26], while the $\mathrm{CO}$ adsorption at bridge or hollow site is negligible. It is noteworthy that this $\mathrm{CO}_{\mathrm{L}}$ adsorption band is at lower wavenumber compared to that of $\mathrm{Pt}$ supported on oxide supports (for example $\mathrm{SiO}_{2}$ [48] and $\mathrm{Al}_{2} \mathrm{O}_{3}[26]$, which have this feature generally at 2100 2050 $\mathrm{cm}^{-1}$ ); this redshift can be attributed to CO adsorption mainly on step, edge or kink sites of the small Pt nanoparticles ( 1-1.5 nm)[24, 49, 50] used in our study. In comparison of the peak area, Re addition causes about 50\% reduction in the CO peak area and 
agrees quite well with the abovementioned CO chemisorption results (Table 1) that Pt dispersion decreases from $85.1 \%$ to $46.6 \%$ after adding Re. Besides the reduction in peak area, a slight redshift from 2035 to $2030 \mathrm{~cm}^{-1}$ is also noticeable upon adding Re. This appears in accordance with previous reports that redshifts were generally found upon adding Re to Pt catalysts[43, 44, 51]. Such a redshift also seems to suggest stronger CO adsorption on Pt-Re/C.
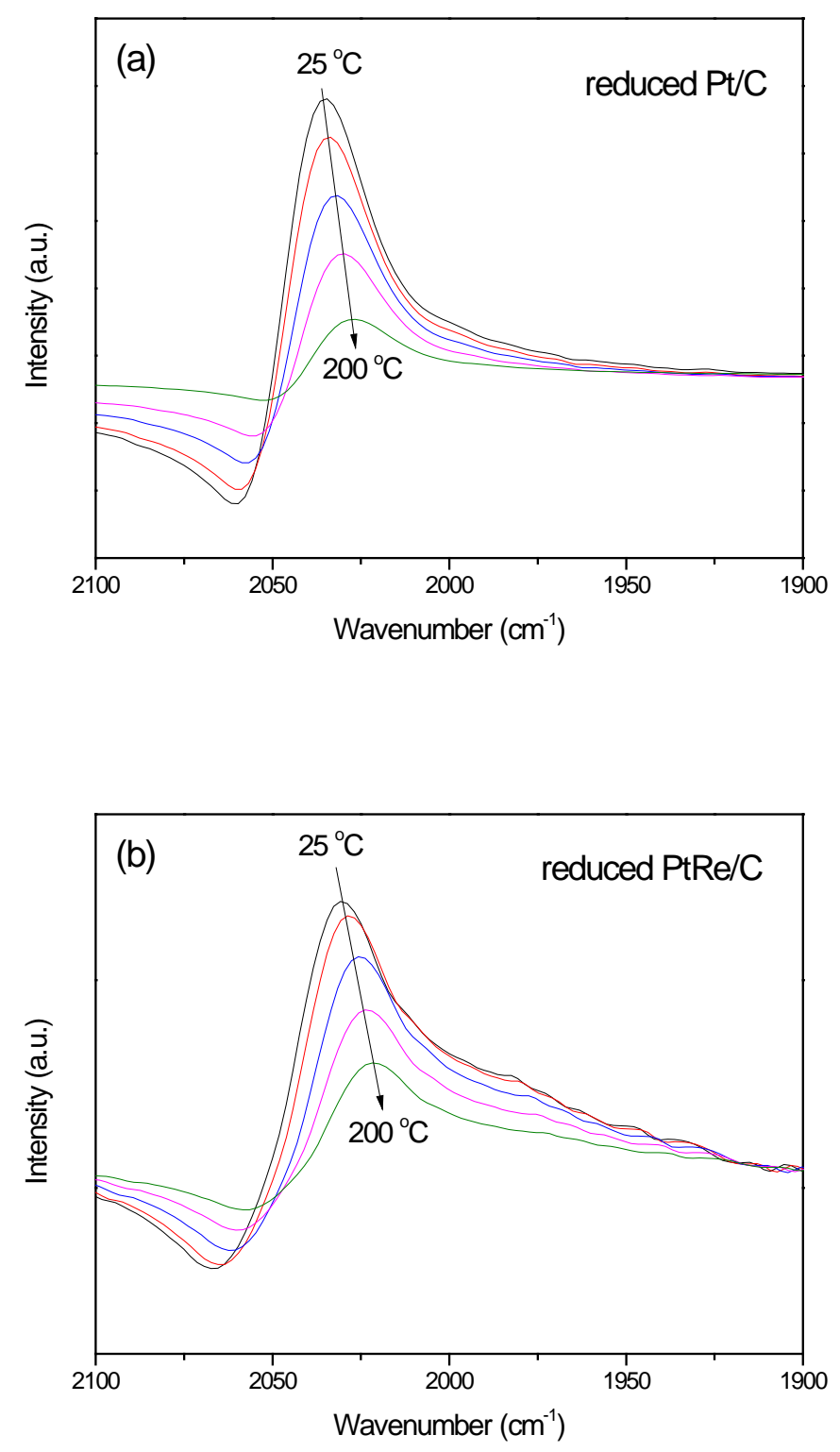


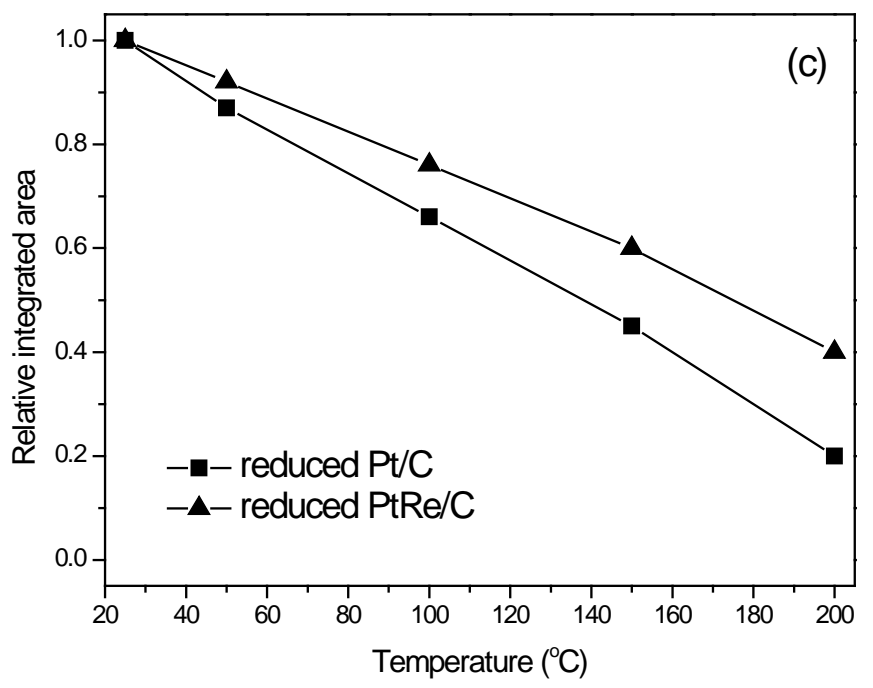

Fig. 6 CO ATR-IRS with respect to desorption temperatures (25, 50, 100, 150 and $200{ }^{\circ} \mathrm{C}$ ) over reduced catalysts (a) Pt/C and (b) Pt-Re/C and (c) the integrated CO adsorption peak area relative to that at $25^{\circ} \mathrm{C}$ in (a) and (b) as a function of desorption temperature of $\mathrm{Pt} / \mathrm{C}(\boldsymbol{\square})$ and $\mathrm{Pt}-\mathrm{Re} / \mathrm{C}(\boldsymbol{\Delta})$

To further differentiate between the CO binding strength on Pt and Pt-Re we performed CO-TPD observed by ATR-IR. Fig. 6 shows the CO desorption profile as a function of evacuation temperature of the reduced $\mathrm{Pt} / \mathrm{C}$ and $\mathrm{Pt}-\mathrm{Re} / \mathrm{C}$ catalysts. As the evacuation temperature increases the peak maxima in Fig. 6(a, b) is red-shifted, which is consistent with literature[43] and indicates that only stronger CO adsorption is present at elevated temperatures. In Fig. 6(a), the CO peak area of Pt/C catalyst decreases gradually from $100 \%$ at $25{ }^{\circ} \mathrm{C}$ to about $20 \%$ at $200{ }^{\circ} \mathrm{C}$. The Pt$\mathrm{Re} / \mathrm{C}$ catalyst in Fig. 6(b) shows a similar decreasing trend, but to a lesser extent. At $200{ }^{\circ} \mathrm{C}$ about $40 \%$ peak area still persists. Therefore, the metal-CO bond is expected to be stronger over the reduced Pt-Re/C catalyst resulting in higher $\mathrm{CO}$ desorption temperature. In Fig. 6(c) both catalysts show approximately linear decrease of the integrated peak area of CO adsorption as a function of temperature. As the slope indicates, CO desorbs more rapidly from Pt/C than Pt-Re/C as the temperature increases. 


\section{Properties under steam environment}

Metallic Re can be readily oxidized by steam at low temperatures[16] and even in reformate with hydrogen present[44]. Therefore, it is very likely that oxidized Re species exists on the PtRe/C catalyst surface after steam exposure. To investigate the structure of such species and further understand its role in the catalytic performance, in situ Raman experiments were carried out. Fig. 7 depicts the Raman spectra of Pt-Re/C catalyst with treatment of reduction and reduction followed by steam exposure, respectively. The reduced sample shows only one vibrational feature at $478 \mathrm{~cm}^{-1}$ over the entire spectrum range. The absence of terminal ReO vibrational mode (located at above $880 \mathrm{~cm}^{-1}$ )[52] is consistent with the EXAFS result in Table 3 showing low $\mathrm{CN}_{\mathrm{Re}-\mathrm{O}}$. A M-Re-O-Re linkage can thus be inferred to be associated to the $478 \mathrm{~cm}^{-1}$ feature. Compared to the Re-O-Re symmetric stretching mode located at $\sim 456 \mathrm{~cm}^{-1}$ for gaseous $\operatorname{Re}_{2} \mathrm{O}_{7}$ [52], a blueshift of $18 \mathrm{~cm}^{-1}$ could be a result of the low Re oxidation state and/or small coordination of the $\mathrm{ReO}_{\mathrm{x}}$ clusters[53, 54]. Introduction of steam following reduction does not

change this feature but generates a prominent Raman band at $995 \mathrm{~cm}^{-1}$. According to the literature[55], the latter could be assigned to terminal ReO symmetric stretching from tetrahedrally coordinated $\mathrm{ReO}_{4}$ unit[56] on catalyst surface. As Re also facilitates water activation[19, 57], it is also probable that under reaction condition Re can get hydrolyzed to form Re-OH which may decompose to form $\mathrm{ReO}_{\mathrm{x}}$ once dehydrated. 


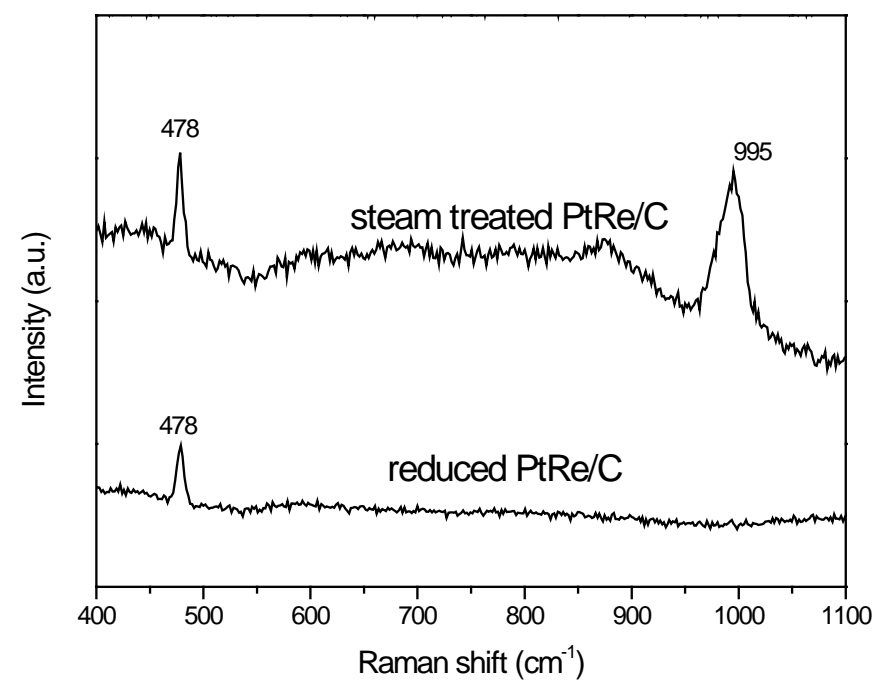

Fig. 7 Raman spectra of PtRe/C catalyst with different treatments

To provide further details on the interaction with adsorbates, we characterized the Pt-Re catalyst at the Re $\mathrm{L}_{3}$ edge using XANES before and after steam exposure. Fig. 8(a) shows the Re $\mathrm{L}_{3}$ spectra for the Re foil as well as the calcined and reduced catalysts, respectively. Consistent with the EXAFS results, the XANES spectra show that Re consists of a mixture of Re metal and $\mathrm{ReO}_{\mathrm{x}}$. In our previous work on Pt-Re/C, we showed by XPS that Re gets oxidized by steam[16]. However, the exposure to steam and $\mathrm{H}_{2}$ mixture was not studied and it is not clear if Re oxidation would occur under the reaction conditions where the gas environment is expected to be a mixture including $\mathrm{H}_{2}$, $\mathrm{CO}$ and $\mathrm{H}_{2} \mathrm{O}$. Therefore, we also investigated the effect of exposure to a mixture of $\mathrm{H}_{2} / \mathrm{H}_{2} \mathrm{O}$ compared with $\mathrm{H}_{2} \mathrm{O} / \mathrm{He}$ and the XANES spectra are shown in Fig. 8(b). It can be seen that the edge shifts to higher energy and the white line intensity increases which is consistent with the partial oxidation of Re and/or adsorption of $\mathrm{OH}$ on Re. The effect was more pronounced in the case of $\mathrm{H}_{2} \mathrm{O} / \mathrm{He}$ as expected. Meanwhile, it should also be noted that with steam treatment the XANES spectra of $\mathrm{Pt} \mathrm{L}_{2,3}$ edges in both cases of Pt/C and PtRe/C (Fig. S2) show changes consistent with $\mathrm{OH}$ adsorption on Pt ( $\triangle \mathrm{XANES}$ can be found in Fig. S2) and the comparison 
between Pt/C and Pt-Re/C showed similar differences as the spectra collected under He. The calculation of the fractional change in unoccupied d states under steam was 0.08 and 0.12 for Pt and Pt-Re, respectively. These results suggest that, under steam environment, Re doesn't appear to significantly affect the electronic properties of Pt. To provide more insights into the effect of steam on the Pt and Pt-Re interaction with adsorbates, the strength of CO adsorption was further investigated by CO-TPD using ATR-IR and explained below.

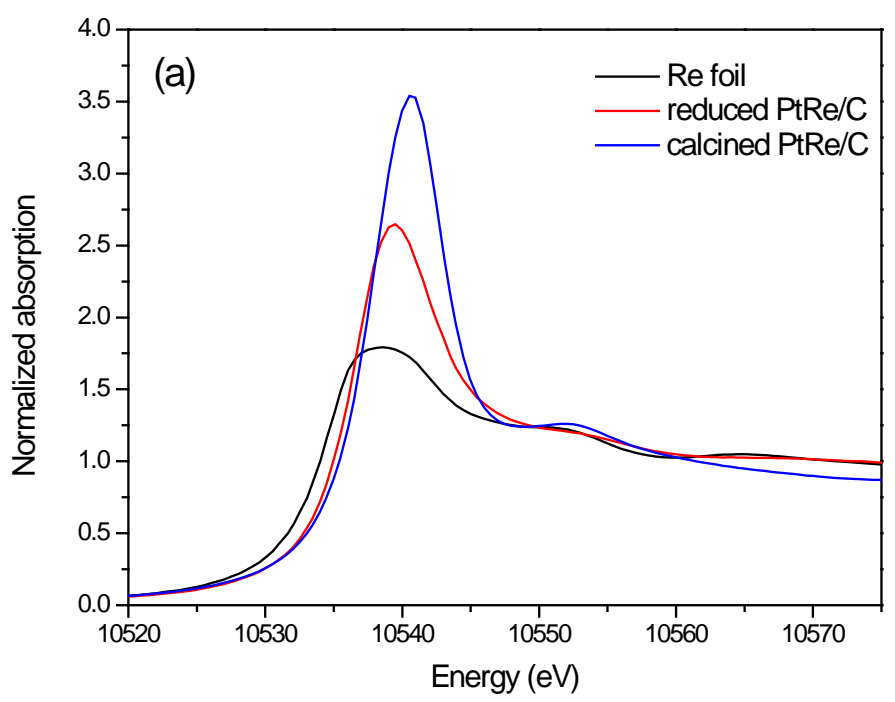




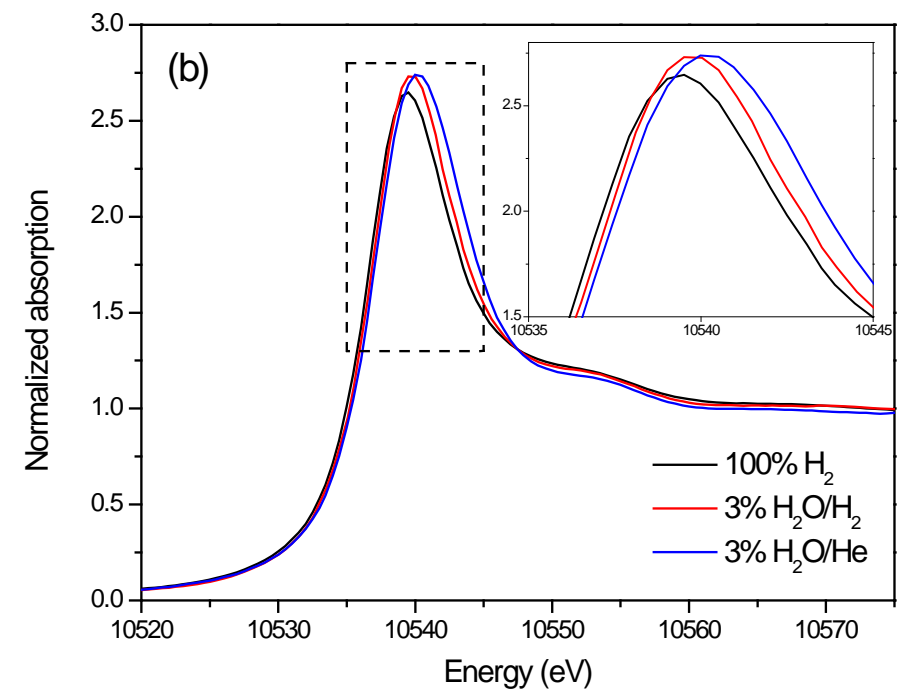

Fig. 8 Re $\mathrm{L}_{3}$ XANES for (a) Re foil, calcined, and reduced Pt-Re/C. The spectrum for the calcined catalyst was collected in air at room temperature while the spectrum of the reduced catalyst was collected in $100 \% \mathrm{H}_{2}$ flow at $225{ }^{\circ} \mathrm{C}$; (b) Pt-Re/C catalyst under $100 \% \mathrm{H}_{2}, 3 \%$ $\mathrm{H}_{2} \mathrm{O} / \mathrm{H}_{2}$ and $3 \% \mathrm{H}_{2} \mathrm{O} / \mathrm{He}$ (inset showing enlarged view of the white line).

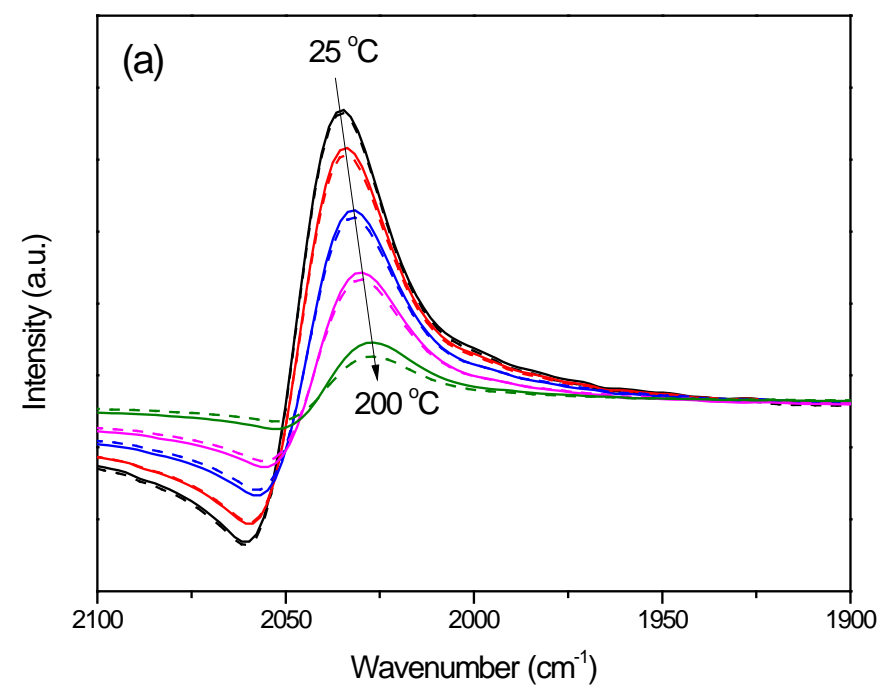




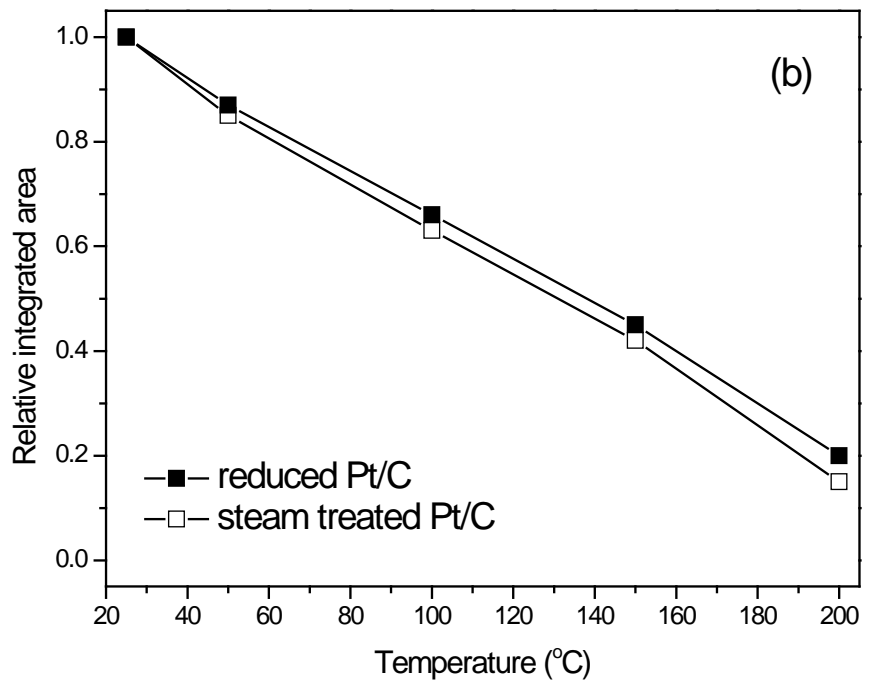

Fig. 9 CO ATR-IRS with respect to desorption temperatures (25, 50, 100, 150 and $200{ }^{\circ} \mathrm{C}$ ) over (a) reduced (solid line) and steam treated (dash line) Pt/C catalysts and (b) the integrated CO adsorption peak area relative to that at $25^{\circ} \mathrm{C}$ in (a) as a function of desorption temperature of reduced ( $\square$ ) and reduced-steam exposed ( $\square$ ) Pt/C catalysts The spectra in (a) were normalized by the $\mathrm{CO}$ adsorption peak area at $25^{\circ} \mathrm{C}$.

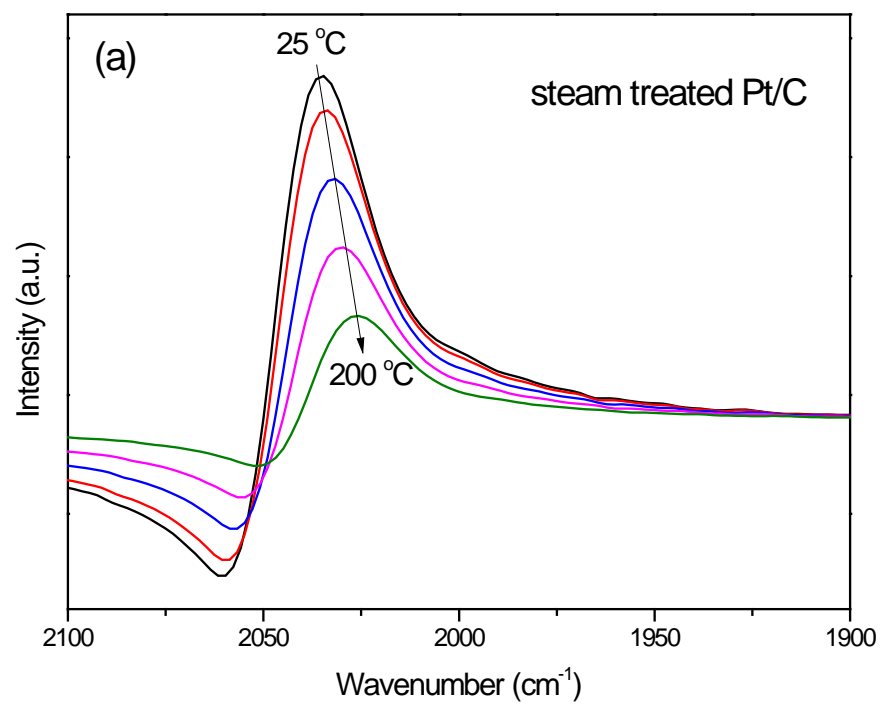



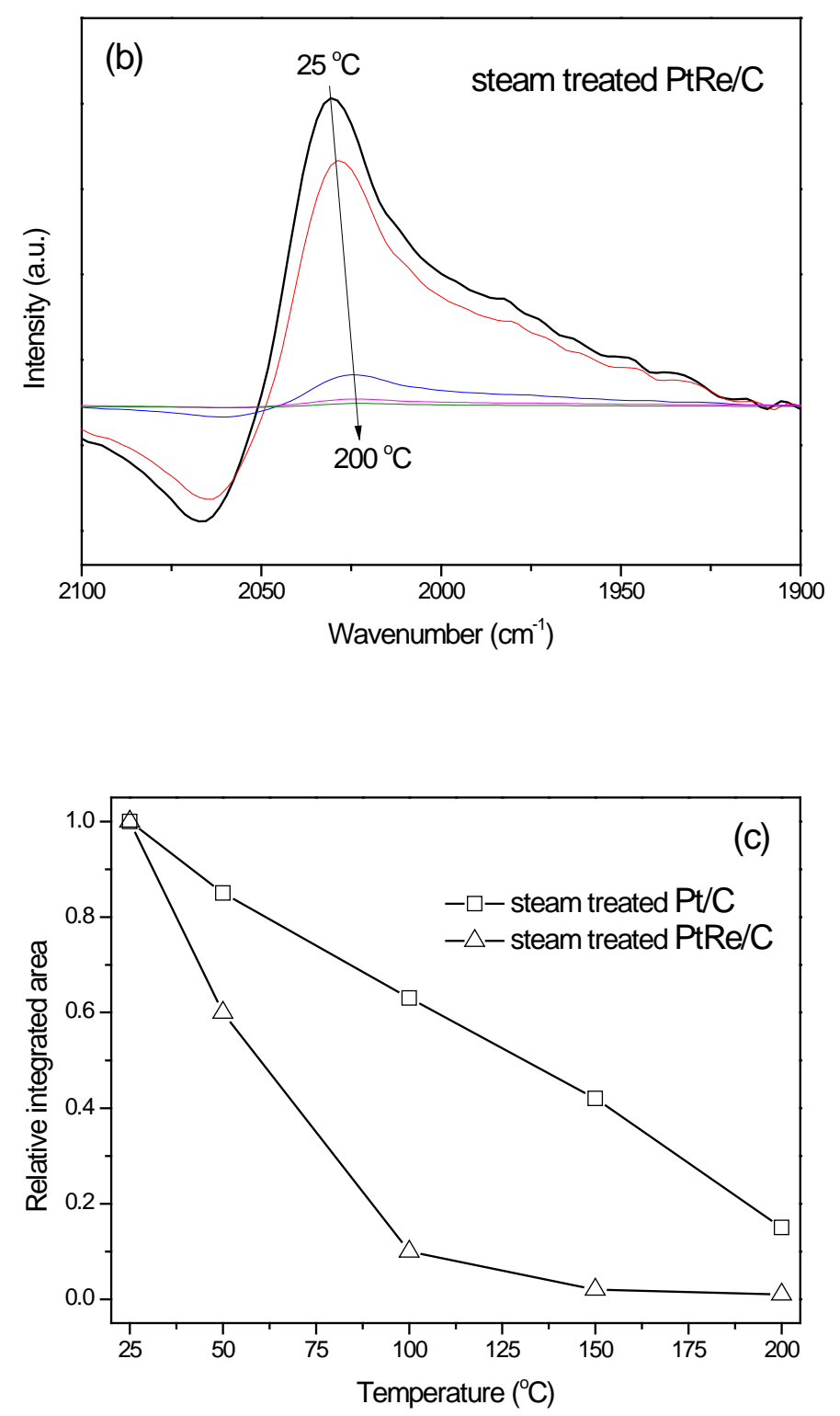

Fig. 10 CO ATR-IRS with respect to desorption temperatures (25, 50, 100, 150 and $200{ }^{\circ} \mathrm{C}$ ) over reduction-steam treated catalysts (a) Pt/C and (b) Pt-Re/C and (c) the integrated CO adsorption peak area relative to that at $25^{\circ} \mathrm{C}$ in (a) and (b) as a function of desorption temperature of the two catalysts $\mathrm{Pt} / \mathrm{C}(\square)$ and Pt-Re/C $(\Delta)$ 
The catalysts were exposed to steam environment at the reaction temperature before introducing CO. As can be seen in Fig. 9(a), steam treatment caused insignificant changes in the CO desorption profile of $\mathrm{Pt} / \mathrm{C}$ catalyst. The peak position at each evacuation temperature does not seem to shift, and the peak area is quite similar. The similar CO-TPD profile in Fig. 9(b) suggests that steam treatment yields little difference in CO desorption behavior. The spectra at room temperature were also similar for both the reduced and steam treated Pt-Re catalyst with a peak maximum around $2030 \mathrm{~cm}^{-1}$ which would indicate a slightly stronger adsorption compared to the Pt/C (C-O vibrational frequency of $2035 \mathrm{~cm}^{-1}$ ) even after exposure to steam. However, for the bimetallic catalyst, steam treatment appears to have a great effect on the CO desorption profile. In Fig. 10, the steam treated Pt-Re/C catalyst showed a rapid decrease in CO peak area with about only $10 \%$ left at $100{ }^{\circ} \mathrm{C}$ and almost complete desorption before reaching $150{ }^{\circ} \mathrm{C}$. Such a big change indicates that although Re renders stronger CO adsorption on Pt, steam exposure exerts a prominent effect to facilitate CO desorption from the catalyst surface during TPD. By comparing the CO-TPD profile of the reduced and steam treated Pt-Re/C catalyst (shown in Fig. S3), we found that the shift of CO peak maxima at each evacuation temperature is negligible (due to their low intensity the desorption peak position of the steam treated sample at 150 and $200{ }^{\circ} \mathrm{C}$, these spectra were not compared). This is rather surprising since a lower desorption temperature would typically be reflected in a higher C-O vibrational frequency which was not observed $\left(2030 \mathrm{~cm}^{-1}\right.$ at room temperature for both the reduced and steam treated Pt-Re/C). Therefore, it appears that the electronic properties of Pt are not directly affected by Re oxidation under steam environment which is in agreement with the XANES results. One possible mechanism to explain the more facile desorption of CO from Pt-Re/C after steam treatment is that CO could be spilt over from Pt to the neighboring $\mathrm{Re}-\mathrm{O}(\mathrm{H})$ and either desorbs or further reacts to form $\mathrm{CO}_{2}$ which will be investigated further below. 
To investigate whether the interaction with $\mathrm{CO}$ is limited to Pt sites, the Pt-Re/C catalyst was exposed to steam followed by $\mathrm{CO}$ at $225^{\circ} \mathrm{C}$ and the Re $\mathrm{L}_{3}$ XANES spectra are shown in Fig. 11. As opposed to steam which renders $\mathrm{Re} \mathrm{L}_{3}$ edge shift towards higher energy as well as an increase in the white line intensity, subsequent $\mathrm{CO}$ exposure appears to have a completely reverse effect. This shows that $\mathrm{CO}$ does interact with $\mathrm{ReO}_{\mathrm{x}} / \mathrm{ReO}(\mathrm{H})$ species present on the catalyst surface, reducing the majority of Re that was oxidized by steam and/or removing most of the hydroxyl groups. Since direct adsorption of $\mathrm{CO}$ onto $\mathrm{Re}$ or $\mathrm{ReO}_{\mathrm{x}}$ is unfavorable, such interaction is likely through the spillover of CO adsorbed on Pt. In contrast to our previous work on glycerol APR[16], the selectivity of Pt toward $\mathrm{C}-\mathrm{O}$ cleavage (dehydration pathway) in steam reforming of glycerol was not significantly affected by the addition Re. This suggests that the oxidizing power of steam could be weaker than that of liquid water resulting in lower extent of Re oxidation and less strong and/or lower number of acid sites which is the subject of an ongoing study.

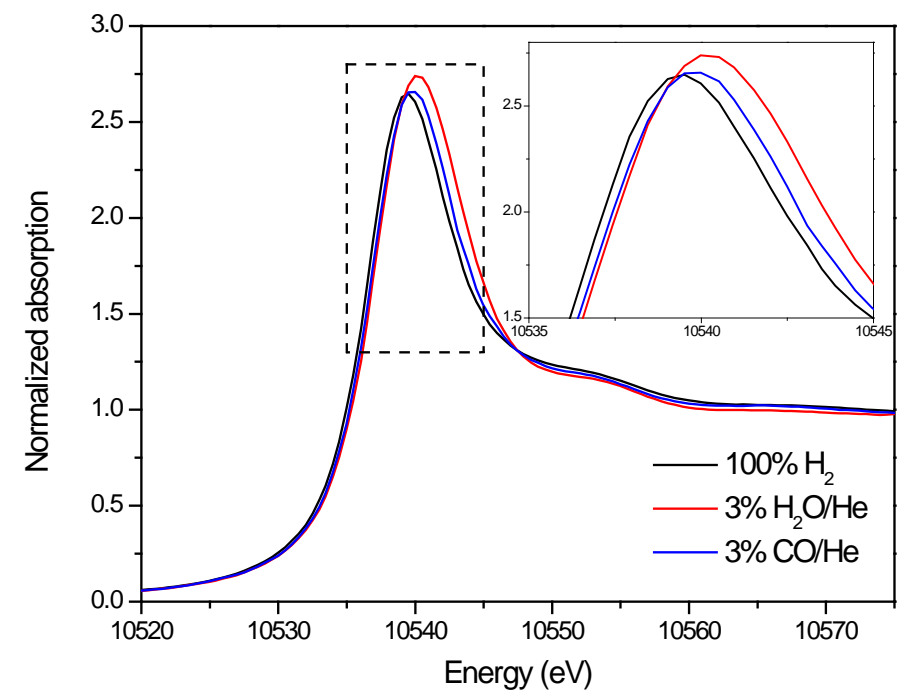

Fig. 11 Re $\mathrm{L}_{3}$ XANES for the PtRe/C catalyst under 100\% $\mathrm{H}_{2}, 3 \% \mathrm{H}_{2} \mathrm{O} / \mathrm{He}$ and $3 \% \mathrm{CO} / \mathrm{He}$ (inset showing enlarged view of the white line). 
The preferable reaction pathway of glycerol reforming to produce hydrogen should consist of dehydrogenation and decarbonylation. It is generally accepted that Pt surface can catalyze dehydrogenation[9] and a small portion of dehydration[25] of glycerol. The questions such as how the addition of Re affects the overall catalytic activity and how the reaction medium can further influence it still remain. The primary role of Re is believed to be enhancing the activity of Pt/C catalyst and has been previously attributed to the weakened interaction between CO and alloyed Pt-Re[11, 12]. However, our results in the present study on the reduced catalysts do not support this hypothesis, which showed that Re addition tends to strengthen CO adsorption on Pt. Here we found that the presence of oxidized Re species affects the CO desorption from Pt. Our ATR-IR results of CO adsorption and TPD over Pt-Re/C showed that the Pt-CO bond strength was not affected by steam treatment at $25{ }^{\circ} \mathrm{C}$ but $\mathrm{CO}$ desorption was facilitated as the temperature was ramped up compared with that of the reduced Pt-Re/C. We propose a schematic of the catalyst surface and the effect of steam based on our ATR-IRS, XAS and Raman results in Scheme 1. The catalyst structure consists of Pt-Re nanoparticles with a surface rich in a mixture of $\mathrm{Re}$ and $\mathrm{ReO}_{\mathrm{x}}$ and the amount of $\mathrm{Re}-\mathrm{O}(\mathrm{H})$ increases under steam. On such a surface, Pt likely acts as the adsorption and main reaction site, while $\mathrm{Re}-\mathrm{O}(\mathrm{H})$ could provide the site for temporal accommodation of $\mathrm{CO}$ to allow the spillover from the Pt site and allow for its more facile desorption or WGS reaction. We believe that this scheme is also supported by the catalytic reaction and characterization results. As can be seen in Table 2, the $\mathrm{CO} / \mathrm{CO}_{2}$ ratio is lowered by about 1/3 in the case of Pt-Re/C compared to Pt/C, indicating that $\mathrm{CO}$ transformation to $\mathrm{CO}_{2}$ is more favored on Pt-Re/C rather than directly desorbing from the Pt sites. Combined with the Re $\mathrm{L}_{3}$ XANES results showing interaction of $\mathrm{CO}$ with $\mathrm{Re} / \mathrm{Re}-\mathrm{O}(\mathrm{H})$ (Figure 11), CO spillover is highly possible to occur through such Pt-Re-O(H) interaction. This synergy allows for higher turnover of glycerol (or CO for WGS). This is also in agreement with previous reports that Re in an oxidized state (e.g., $\mathrm{ReO}_{x}$ ) could provide sites for $\mathrm{CO}$ oxidation[32] and water activation[19]. Therefore, it is still valid that the overall effect of Re under reaction conditions is to facilitate CO 
removal from the Pt sites; however, the effect does not appear to be related to modification of the Pt electronic properties but rather through spillover of CO to the neighboring Re-O(H) sites where it can either desorb or react with $\mathrm{Re}-\mathrm{O}(\mathrm{H})$ to form $\mathrm{CO}_{2}$.
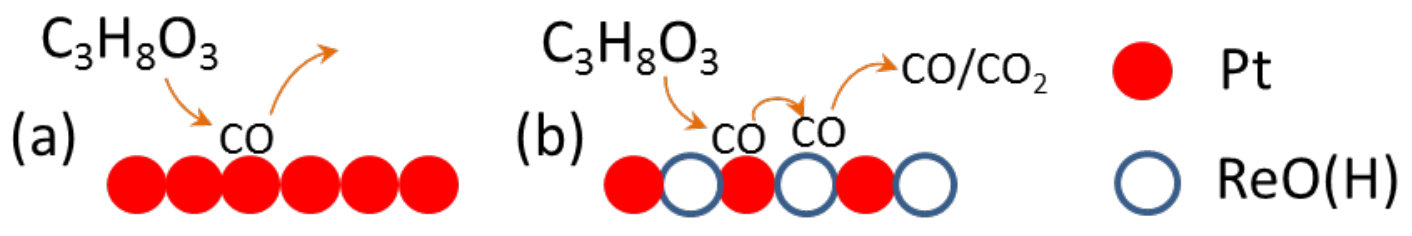

Scheme 1 Steam reforming of glycerol over Pt/C (a) and PtRe/C (b) catalysts

\section{Conclusions}

Compared to monometallic Pt/C catalyst, bimetallic PtRe/C catalyst exhibits significantly increased activity, $\mathrm{H}_{2} / \mathrm{CO}_{\mathrm{x}}$ ratio, and $\mathrm{CO}_{2}$ selectivity in glycerol steam reforming. Using a suite of complementary in situ techniques (CO ATR-IR, XAS, and Raman), we found that the Pt-Re/C catalyst consists of $\mathrm{Re} / \mathrm{ReO}_{\mathrm{x}}$ rich surface which slightly modifies the electronic properties of Pt, leading to stronger $\mathrm{CO}$ adsorption on the bimetallic catalyst. After steam exposure, $\mathrm{Re} / \mathrm{ReO} \mathrm{O}_{\mathrm{x}}$ gets more oxidized but does not have a strong effect on the electronic properties of Pt. As a result, the C-O vibrational frequency was not affected by steam on either Pt/C or Pt-Re/C. However, CO desorption was much more facile from the steam treated Pt-Re/C. We propose that the oxidation of Re in the presence of steam provides a redox site for the CO spillover, on which CO can easily desorb or react to form $\mathrm{CO}_{2}$. This spillover effect is believed to be mainly responsible for the enhanced activity and $\mathrm{CO}_{2}$ selectivity in glycerol steam reforming. 


\section{Acknowledgements}

The authors acknowledge financial support from the U.S. Department of Energy, Office of Energy Efficiency and Renewable Energy, from the National Advanced Biofuels Consortium, which is funded by the Department of Energy's Office of Biomass Program with recovery act funds, and from the U.S. Department of Energy, Office of Basic Energy Sciences (grant No. DEFG02-05ER15712). Use of the National Synchrotron Light Source, Brookhaven National Laboratory, for the EXAFS experiments was supported by the US Department of Energy, Office of Basic Energy Sciences (Grant\# DE-FG02-05ER15688). Beam line X18A is supported, in part, by the Synchrotron Catalysis Consortium. Z.W. would like to thank Stephen Davidson (Washington State University) for his help with the reaction setup. A.M.K. would like to thank Yongchun Hong (Washington State University) for his help with the XAS data collection. 


\section{References}

[1] G.W. Huber, S. Iborra, A. Corma, Chemical Reviews, 106 (2006) 4044.

[2] E.L. Kunkes, D.A. Simonetti, R.M. West, J.C. Serrano-Ruiz, C.A. Gärtner, J.A. Dumesic, Science, 322 (2008) 417.

[3] J.N. Chheda, G.W. Huber, J.A. Dumesic, Angewandte Chemie-International Edition, 46 (2007) 7164.

[4] R.D. Cortright, R.R. Davda, J.A. Dumesic, Nature, 418 (2002) 964.

[5] Z. Wei, J. Sun, Y. Li, A.K. Datye, Y. Wang, Chemical Society Reviews, 41 (2012) 7994.

[6] G.W. Huber, J.N. Chheda, C.J. Barrett, J.A. Dumesic, Science, 308 (2005) 1446.

[7] Y. Roman-Leshkov, C.J. Barrett, Z.Y. Liu, J.A. Dumesic, Nature, 447 (2007) 982.

[8] F.R. Ma, M.A. Hanna, Bioresource Technology, 70 (1999) 1.

[9] Y.-C. Lin, International Journal of Hydrogen Energy, 38 (2013) 2678.

[10] P.D. Vaidya, A.E. Rodrigues, Chemical Engineering \& Technology, 32 (2009) 1463.

[11] D.A. Simonetti, E.L. Kunkes, J.A. Dumesic, Journal of Catalysis, 247 (2007) 298.

[12] E.L. Kunkes, D.A. Simonetti, J.A. Dumesic, W.D. Pyrz, L.E. Murillo, J.G.G. Chen, D.J. Buttrey, Journal of Catalysis, 260 (2008) 164.

[13] L. Zhang, A.M. Karim, M.H. Engelhard, Z.H. Wei, D.L. King, Y. Wang, Journal of Catalysis, 287 (2012) 37.

[14] S.A. Tupy, A.M. Karim, C. Bagia, W. Deng, Y. Huang, D.G. Vlachos, J.G. Chen, ACS Catalysis, 2 (2012) 2290.

[15] B.M. Weckhuysen, Chemical Society Reviews, 39 (2010) 4557.

[16] A.M. Karim, C. Howard, B. Roberts, L. Kovarik, L. Zhang, D.L. King, Y. Wang, ACS Catalysis, 2 (2012) 2387.

[17] J. Xiao, R.J. Puddephatt, Coordination Chemistry Reviews, 143 (1995) 457.

[18] A. Ciftci, D.A.J.M. Ligthart, A.O. Sen, A.J.F. van Hoof, H. Friedrich, E.J.M. Hensen, Journal of Catalysis, 311 (2014) 88.

[19] K.G. Azzam, I.V. Babich, K. Seshan, B.L. Mojet, L. Lefferts, ChemCatChem, 5 (2013) 557.

[20] D.L. King, L.A. Zhang, G. Xia, A.M. Karim, D.J. Heldebrant, X.Q. Wang, T. Peterson, Y. Wang, Applied Catalysis B-Environmental, 99 (2010) 206.

[21] M. Newville, Journal of Synchrotron Radiation, 8 (2001) 96.

[22] B. Ravel, M. Newville, Journal of Synchrotron Radiation, 12 (2005) 537.

[23] S.R. Bare, S.D. Kelly, F. D.Vila, E. Boldingh, E. Karapetrova, J. Kas, G.E. Mickelson, F.S. Modica, N. Yang, J.J. Rehr, The Journal of Physical Chemistry C, 115 (2011) 5740.

[24] B. Roldan Cuenya, J.R. Croy, S. Mostafa, F. Behafarid, L. Li, Z. Zhang, J.C. Yang, Q. Wang, A.I. Frenkel, Journal of the American Chemical Society, 132 (2010) 8747.

[25] A. Wawrzetz, B. Peng, A. Hrabar, A. Jentys, A.A. Lemonidou, J.A. Lercher, Journal of Catalysis, 269 (2010) 411.

[26] B.L. Mojet, S.D. Ebbesen, L. Lefferts, Chemical Society Reviews, 39 (2010) 4643.

[27] Y. Li, Z. Wei, J. Sun, F. Gao, C.H.F. Peden, Y. Wang, The Journal of Physical Chemistry C, 117 (2013) 5722.

[28] C.L. Pieck, C.R. Vera, J.M. Parera, G.N. Giménez, L.R. Serra, L.S. Carvalho, M.C. Rangel, Catalysis Today, 107-108 (2005) 637.

[29] L. Zhang, G. Xia, Y. Yang, D. Heldebrant, D. King, Y. Wang, L. Allard, Microscopy and Microanalysis, 16 (2010) 1454. 
[30] P. Biloen, J.N. Helle, H. Verbeek, F.M. Dautzenberg, W.M.H. Sachtler, Journal of Catalysis, 63 (1980) 112.

[31] R. Burch, Platinum Metals Review, 22 (1978) 61.

[32] Y. Ishida, T. Ebashi, S.-i. Ito, T. Kubota, K. Kunimori, K. Tomishige, Chemical Communications, (2009) 5308.

[33] W. Daniell, T. Weingand, H. Knözinger, Journal of Molecular Catalysis A: Chemical, 204-205 (2003) 519.

[34] Y. Lei, J. Jelic, L. Nitsche, R. Meyer, J. Miller, Topics in Catalysis, 54 (2011) 334.

[35] A. Yevick, A.I. Frenkel, Physical Review B, 81 (2010) 115451.

[36] S.I. Sanchez, L.D. Menard, A. Bram, J.H. Kang, M.W. Small, R.G. Nuzzo, A.I. Frenkel, Journal of the American Chemical Society, 131 (2009) 7040.

[37] A.I. Frenkel, Q. Wang, S.I. Sanchez, M.W. Small, R.G. Nuzzo, Journal of Chemical Physics, 138 (2013).

[38] A.I. Frenkel, Chemical Society Reviews, 41 (2012) 8163.

[39] Y. A, F. Al, Phys. Rev. B, 81 (2010) 115451.

[40] A. Ramstad, F. Strisland, S. Raaen, A. Borg, C. Berg, Surface Science, 440 (1999) 290.

[41] Y. Ishikawa, M.-S. Liao, C.R. Cabrera, Surface Science, 513 (2002) 98.

[42] J. Greeley, M. Mavrikakis, Catalysis Today, 111 (2006) 52.

[43] Y. Sato, K. Terada, S. Hasegawa, T. Miyao, S. Naito, Applied Catalysis A-General, 296 (2005) 80.

[44] W. Ruettinger, X. Liu, X. Xu, R. Farrauto, Topics in Catalysis, 51 (2008) 60.

[45] A.N. Mansour, J.W. Cook, D.E. Sayers, The Journal of Physical Chemistry, 88 (1984) 2330.

[46] F.W. Lytle, R.B. Greegor, E.C. Marques, D.R. Sandstrom, G.H. Via, J.H. Sinfelt, Journal of Catalysis, 95 (1985) 546.

[47] N. Schweitzer, H. Xin, E. Nikolla, J. Miller, S. Linic, Topics in Catalysis, 53 (2010) 348.

[48] P.T. Fanson, W.N. Delgass, J. Lauterbach, Journal of Catalysis, 204 (2001) 35.

[49] B. Qiao, A. Wang, X. Yang, L.F. Allard, Z. Jiang, Y. Cui, J. Liu, J. Li, T. Zhang, Nature Chemistry, 3 (2011) 634.

[50] L.C. deMenorval, A. Chaqroune, B. Coq, F. Figueras, Journal of the Chemical Society-Faraday Transactions, 93 (1997) 3715.

[51] T. Ebashi, Y. Ishida, Y. Nakagawa, S.-i. Ito, T. Kubota, K. Tomishige, The Journal of Physical Chemistry C, 114 (2010) 6518.

[52] M.A. Vuurman, D.J. Stufkens, A. Oskam, I.E. Wachs, Journal of Molecular Catalysis, 76 (1992) 263.

[53] L. Wang, W.K. Hall, Journal of Catalysis, 82 (1983) 177.

[54] H.S. Lacheen, P.J. Cordeiro, E. Iglesia, Chemistry - A European Journal, 13 (2007) 3048.

[55] K.P.J. Williams, K. Harrison, Journal of the Chemical Society-Faraday Transactions, 86 (1990) 1603.

[56] F.D. Hardcastle, I.E. Wachs, J.A. Horsley, G.H. Via, Journal of Molecular Catalysis, 46 (1988) 15.

[57] R. Carrasquillo-Flores, J.M.R. Gallo, K. Hahn, J.A. Dumesic, M. Mavrikakis, ChemCatChem, 5 (2013) 3690. 


\section{Figure Captions:}

Fig. 1 Schematic of ATR cell

Fig. 2 Schematic of ATR-IR experimental setup

Fig. 3 TOF of glycerol $\left(\mathrm{min}^{-1}\right)$ and product selectivity for steam reforming of $10 \mathrm{wt} . \%$ glycerol aqueous solution over 3\%Pt/C and 3\%Pt-3\%Re/C at $225{ }^{\circ} \mathrm{C}$ and ambient pressure

Fig. 4 Pt $\mathrm{L}_{3}$ (a) and $\mathrm{L}_{2}$ (b) XANES for reduced Pt/C and PtRe/C in He at $225{ }^{\circ} \mathrm{C}$

Fig. 5 CO ATR-IRS of reduced 3\%Pt/C and 3\%Pt-3\%Re/C at $25^{\circ} \mathrm{C}$

Fig. 6 CO ATR-IRS with respect to desorption temperatures (25, 50, 100, 150 and $\left.200{ }^{\circ} \mathrm{C}\right)$ over reduced catalysts (a) Pt/C and (b) PtRe/C and (c) the integrated CO adsorption peak area relative to that at $25^{\circ} \mathrm{C}$ in (a) and (b) as a function of desorption temperature of $\mathrm{Pt} / \mathrm{C}(\boldsymbol{\bullet})$ and $\mathrm{PtRe} / \mathrm{C}(\boldsymbol{\Delta})$

Fig. 7 Raman spectra of PtRe/C catalyst with different treatments

Fig. $8 \mathrm{Re} \mathrm{L}_{3}$ XANES for (a) Re foil, calcined, and reduced PtRe/C. The spectrum for the calcined catalyst was collected in air at room temperature while the spectrum of the reduced catalyst was collected in $100 \% \mathrm{H}_{2}$ flow at $225{ }^{\circ} \mathrm{C}$; (b) PtRe/C catalyst under $100 \% \mathrm{H}_{2}$, 3\% $\mathrm{H}_{2} \mathrm{O} / \mathrm{H}_{2}$ and $3 \% \mathrm{H}_{2} \mathrm{O} / \mathrm{He}$ (inset showing enlarged view of the white line).

Fig. 9 CO ATR-IRS with respect to desorption temperatures (25, 50, 100, 150 and $200{ }^{\circ} \mathrm{C}$ ) over (a) reduced (solid line) and reduction-steam treated (dash line) Pt/C catalysts and (b) the integrated $\mathrm{CO}$ adsorption peak area relative to that at $25{ }^{\circ} \mathrm{C}$ in (a) as a function of desorption temperature of reduced () and reduced -steam exposed (a) $\mathrm{Pt} / \mathrm{C}$ catalysts The spectra in (a) is normalized by the $\mathrm{CO}$ adsorption peak area at $25^{\circ} \mathrm{C}$.

Fig. 10 CO ATR-IRS with respect to desorption temperatures (25, 50, 100, 150 and $\left.200{ }^{\circ} \mathrm{C}\right)$ over reduction-steam treated catalysts (a) Pt/C and (b) PtRe/C and (c) the integrated CO adsorption peak area relative to that at $25^{\circ} \mathrm{C}$ in (a) and (b) as a function of desorption temperature of the two catalysts $\mathrm{Pt} / \mathrm{C}(\square)$ and $\mathrm{PtRe} / \mathrm{C}(\Delta)$ 
Fig. 11 Re $\mathrm{L}_{3} \mathrm{XANES}$ for the PtRe/C catalyst under 100\% $\mathrm{H}_{2}, 3 \% \mathrm{H}_{2} \mathrm{O} / \mathrm{He}$ and 3\% CO/He (inset showing enlarged view of the white line). 